Contract Program or Project Title:

Subject of this Document:

Type of Document:

Author:

Date of Document:

Responsible NRC Individual and NRC Office or Division:
Heavy-Section Steel Irradiation (HSSI)

Program, Metals and Ceramics Division

Initial Evaluation of the Heat-Affected Zone, Local Embrittlement Phenomenon as it Applies to Nuclear Reactor Vessels

Letter Report

D. E. McCabe

September 1999

C. J. Fairbanks (301-415-6719)

Division of Engineering Technology

U.S. Nuclear Regulatory Commission

Prepared for the

U.S. Nuclear Regulatory Commission

Washington, DC 20555

Under Interagency Agreement DOE 1886-N695-3W

NRC JCN W6953

OAK RIDGE NATIONAL LABORATORY

Oak Ridge, TN 37831-6151

managed by

LOCKHEED MARTIN ENERGY RESEARCH CORP.

for the

U.S. Department of Energy

under Contract No. DE-AC05-96OR22464 
This report has been reproduced from the best available copy.

Reports are available to the public from the following source.

National Technical Information Service

5285 Port Royal Road

Springfield, VA 22161

Telephone 703-605-6000 (1-800-553-6847)

TDD 703-487-4639

Fax 703-605-6900

E-mail orders@ntis.fedworld.gov

Web site http://www.ntis.gov/ordering.htm

Reports are available to U.S. Department of Energy (DOE) employees, DOE contractors, Energy Technology Data Exchange (ETDE) representatives, and International Nuclear Information System (INIS) representatives from the following source.

Office of Scientific and Technical Information

P.O. Box 62

Oak Ridge, TN 37831

Telephone 423-576-8401

Fax 423-576-5728

E-mail reports@adonis.osti.gov

Web site http://www.osti.gov/products/sources.html

Reports produced after January 1, 1996, are generally available via the DOE Information Bridge. Web site http://www.doe.gov/bridge

This report was prepared as an account of work sponsored by an agency of the United States government. Neither the United States government nor any agency thereof, nor any of their employees, makes any warranty, express or implied, or assumes any legal liability or responsibility for the accuracy, completeness, or usefulness of any information, apparatus, product, or process disclosed, or represents that its use would not infringe privately owned rights. Reference herein to any specific commercial product, process, or service by trade name, trademark, manufacturer, or otherwise, does not necessarily constitute or imply its endorsement, recommendation, or favoring by the United States government or any agency thereof. The views and opinions of authors expressed herein do not necessarily state or reflect those of the United States government or any agency thereof. 


\section{DISCLAIMER}

Portions of this document may be illegible in electronic image products. Images are produced from the best available original document. 


\title{
INITIAL EVALUATION OF THE HEAT-AFFECTED ZONE, LOCAL EMBRITTLEMENT PHENOMENON AS IT APPLIES TO NUCLEAR REACTOR VESSELS
}

\author{
D. E. McCabe \\ Date Published-September 1999 \\ Prepared for the \\ U.S. Nuclear Regulatory Commission \\ Washington, DC 20555 \\ Under Interagency Agreement DOE 1886-N695-3W \\ NRC JCN W6953 \\ OAK RIDGE NATIONAL LABORATORY \\ Oak Ridge, TN 37831-6151 \\ managed by \\ LOCKHEED MARTIN ENERGY RESEARCH CORP. \\ for the \\ U.S. Department of Energy \\ under Contract No. DE-AC05-96OR22464
}




\section{CONTENTS}

\section{Page}

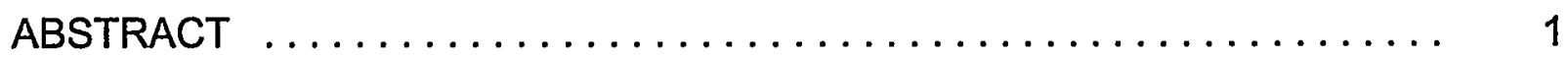

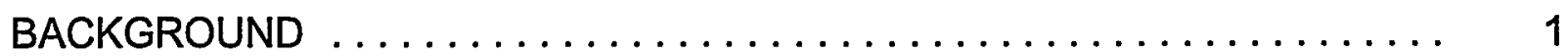

REVIEW OF EXISTING LBZ INFORMATION $\ldots \ldots \ldots \ldots \ldots \ldots \ldots \ldots \ldots$

Assessment of Commonality $\ldots \ldots \ldots \ldots \ldots \ldots \ldots \ldots \ldots \ldots \ldots \ldots$

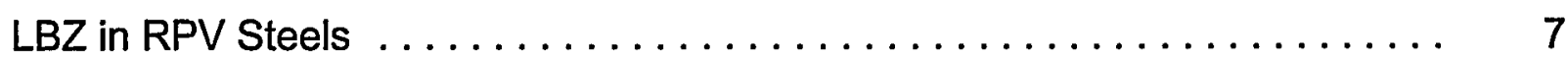

ORNL Evaluation Followup $\ldots \ldots \ldots \ldots \ldots \ldots \ldots \ldots \ldots \ldots \ldots \ldots \ldots \ldots$

Program Plan . . . . . . . . . . . . . . . . 11

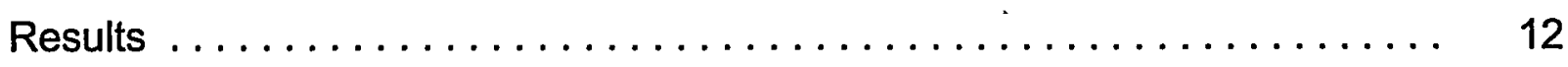

Measurement of Element Diffusion to Grain Boundaries ........... 20

Discussion ................................ 25

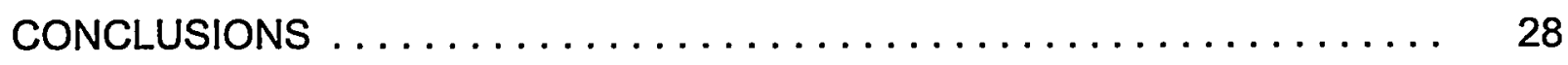

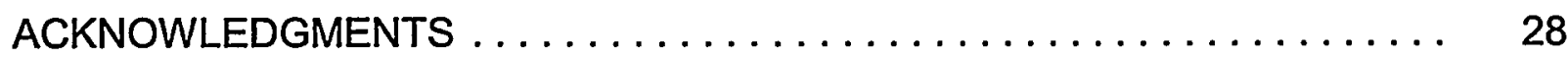

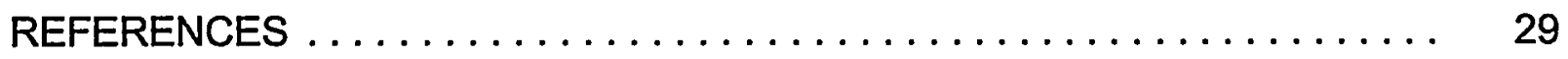

Appendix Examples of HAZ Coarse Grains Along Fusion Line, Fine PriorAustenite Grain Zones, and Base Metal Grains from Three Selected Commercial Welds 


\section{LIST OF FIGURES}

$\begin{array}{lll}\text { Figure } & \text { Page }\end{array}$

1 Schematic representation of microstructures local to the HAZ of multipass welds . . . . . . . . . . . . . 4

2 Cumulative number of chemical samplings made on RPV base metals versus the phosphorus content ..............

$3 \quad$ Example of the as oil-quenched microstructure after the AEA-Technology austenitization and quench cycle, A 533

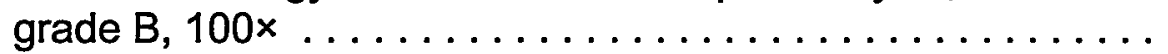

$4 \quad$ Example of the typical microstructure after the AEA-Technology austenitization and PWHT, A 533 grade $B, 100 \times \ldots . \ldots$.

Relationship between initial $T_{0}$ temperature and $\Delta T_{0}$ after

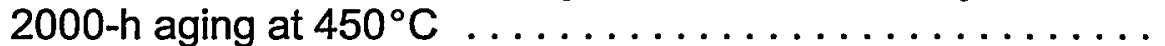

Gleeble-generated weld thermal cycle to develop ASTM 4.5 grain size

Photomicrograph of microstructure after Gleeble austenitization, high-phosphorus modified A 302 grade B, nital etch, 100x ...

Position of CVN $\mathrm{T}_{0}$ temperatures after aging $168 \mathrm{~h}$ at $399^{\circ} \mathrm{C}$, $450^{\circ} \mathrm{C}$, and $482^{\circ} \mathrm{C}$ for $2000 \mathrm{~h}$ at $450^{\circ} \mathrm{C}$ (MA302B stands for modified $A 302$ grade $B) \ldots \ldots \ldots \ldots \ldots \ldots \ldots$ austenitization, PWHT, and $200 \mathrm{~h}$ aging at $450^{\circ} \mathrm{C}$. Charpy lower shelf test temperature $\ldots \ldots \ldots \ldots \ldots \ldots \ldots \ldots$

Phosphorous concentrations in bulk material and grain boundaries. Auger analyses after $2000 \mathrm{~h}$ at $450^{\circ} \mathrm{C}$ temper embrittlement

Fracture surface of material shown in Fig. 9 when tested at an upper shelf temperature . 


\section{LIST OF TABLES}

Table

Page

$1 \quad$ Midtransition temperatures and shifts measured by AEA with CVN specimens . . . . . . . . . . . . . . . . 7

2 Commercial materials selected $\ldots \ldots \ldots \ldots \ldots \ldots \ldots \ldots \quad 8$

3 Summary of chemical analyses $\ldots \ldots \ldots \ldots \ldots \ldots \ldots . . \ldots$

$4 \quad$ Heat-treatment cycles $\ldots \ldots \ldots \ldots \ldots \ldots \ldots \ldots \ldots \ldots \ldots$

5 Grain sizes of the commercially made RPV base metal in their as-received condition $\ldots \ldots \ldots \ldots \ldots \ldots \ldots \ldots \ldots, 10$

6 Revisit of AEA cycles used on five commercially made RPV steels; Phase I transition temperatures, $T_{0}\left({ }^{\circ} \mathrm{C}\right) \ldots \ldots \ldots \ldots .14$

$7 \quad$ Materials austenitized by Gleeble, PWHT, and aged commercially made RPV steels (Phase II and first part of Phase III combined) $\ldots \ldots \ldots \ldots \ldots \ldots \ldots \ldots \ldots \ldots$

8 Largest coarse-grain sizes found in HAZs of six commercially fabricated RPV welds $\ldots \ldots \ldots \ldots \ldots \ldots \ldots \ldots \ldots, 20$

$9 \quad$ Measured increased contents, percent increase of selected elements; grain boundary vs bulk contents . . . . . . . . . 21

10 Comparison of Charpy $\mathrm{V}_{0}$ and fracture-mechanics-based $\mathrm{T}_{100}$

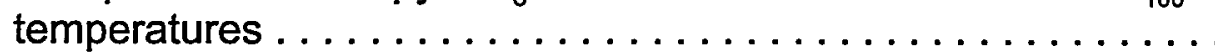




\title{
Initial Evaluation of the Heat-Affected Zone, Local Embrittlement Phenomenon as It Applies to Nuclear Reactor Vessels
}

\author{
D. E. McCabe
}

\begin{abstract}
The objective of this project was to determine if the local brittle zone (LBZ) problem, encountered in the testing of the heat-affected zone (HAZ) part of welds in offshore platform construction, can also be found in reactor pressure vessel (RPV) welds. Both structures have multipass welds and grain coarsening along the fusion line. Literature was obtained that described the metallurgical evidence and the type of research work performed on offshore structure welds. It was determined that other than having multipass welding and coarse prior-austenite grains along the fusion line, there was little else upon which to connect RPV weldments to the LBZ problem in offshore structures. However, coarse prior-austenite grains make RPV steels susceptible to temper embrittlement, an entirely different embrittlement mechanism. Experiments were undertaken to evaluate the potential for temper embrittlement problems in RPV HAZ materials. Enlarged prior-austenite grains were made in bulk using laboratory furnace treatments and in weld cycle simulations using the Gleeble. Five commercially made RPV steels were used in the present study. Embrittlement aging was performed at various temperatures and times. RPV steels with large prior-austenite grain sizes were found to suffer significant temper embrittlement with thermal aging. Because of high carbon equivalent and routine postweld heat treatment that was standard manufacturing practice for RPV production, this project could not make a case that an LBZ type of problem exists in reactor vessels. A final phase of this investigation is to examine the effect of simultaneous irradiation and thermal aging at $288^{\circ} \mathrm{C}\left(550^{\circ} \mathrm{F}\right)$, which can create a critical damage situation. The irradiation exposure is currently in progress.
\end{abstract}




\section{BACKGROUND}

In 1989, Combustion Engineering proposed to the U.S. Nuclear Regulatory Commission (NRC) that consideration be given to replacing the fracture-toughness-based dynamic $K_{\mathbb{R}}$ curve with the quasi-static $K_{1 c}$ curve for setting allowable temperature/ pressure limits during normal and upset conditions. * The idea was accepted for consideration pending the development of clear evidence that there can be no unanticipated trigger sources that would introduce running cleavage cracks.

Such trigger sources could be either crack pop-ins or possibly local brittle zones (LBZs) that reside along the fusion line of multipass weldments. The existence of LBZs was suggested as one of the possibilities for reactor pressure vessel (RPV) weldments.

The objectives of the present project were to (1) review the available LBZ information, (2) determine its applicability to nuclear vessel fabrication and service conditions, and (3) conduct experiments in support of the evaluations.

\section{REVIEW OF EXISTING LBZ INFORMATION}

LBZs in multipass weldments have so far been identified only in offshore platform weldments. ${ }^{1,2}$ At first, offshore platforms were constructed with carbon/manganese grades of steel. Multipass welds in these materials require postweld heat treatment (PWHT) to obtain satisfactory heat-affected zone (HAZ) fracture-toughness properties. Later, in the early 1980 s, the preferred plate material shifted to low-carbon microalloyed steels. ${ }^{3}$ The advantages were clear. Microalloyed steels are given controlled hot-rolling practices to achieve outstanding fracture-toughness properties while retaining good strength properties. At temperatures as low as $-40^{\circ} \mathrm{C}\left(-40^{\circ} \mathrm{F}\right)$, these materials are on the upper shelf of fracture toughness as measured by the Charpy V-notch (CVN) tests, and the energy is typically 260 to $280 \mathrm{~J}$ (190 to $205 \mathrm{ft}-\mathrm{lb}$ ). ${ }^{4}$ Additionally, the lowcarbon content, usually below $0.1 \mathrm{wt} \%$, promotes excellent weldability. The greatest

\footnotetext{
${ }^{*}$ R. K. Nanstad, Travel to Rockville, Maryland, for meeting at the U.S. Nuclear Regulatory Commission, January 9, 1990.
} 
advantage is that no PWHT is required, resulting in highly significant construction cost savings.

The petroleum industry performs fracture-toughness determinations by a crack tip opening displacement (CTOD) test method. ${ }^{5}$ This is a pseudo-fracture-mechanics test method in which a linear displacement measurement at the tip of a fatigue precrack is assumed to have a linear relationship with the fracture-mechanics-based J-integral. A fatigue-precracked bend bar specimen is used. For LBZ evaluations, the precrack is meticulously positioned to be in a grain-coarsened region along the weld fusion line. In replicate tests, some specimens suffer only ductile deformation and consequent slow-stable crack growth.

Two petroleum industry organizations that implement this test procedure in their standards are the American Petroleum Institute ${ }^{6}$ and the Engineering Equipment and Materials Users Association. ${ }^{7}$ The standards are used to qualify a steel manufacturer as a certified producer of LBZ-resistant microalloyed steel. All valid LBZ specimens according to these methods must have a minimum of $15 \%$ coarse grain material along the crack tip. Coarse grain size is generally indicated by American Society for Testing and Materials (ASTM) to be 4.5 or numerically lower. Not all coarse grain material is embrittled material so that proof of a material's susceptibility to LBZ failures in HAZs is never absolute. Weld joint preparation is either " $K$ ". type or "half-K" type, with the intention of making the straightest possible HAZ for test specimen positioning. ${ }^{8}$

Research projects designed to evaluate LBZ damage mechanisms generally use electric resistance heating of specimen blanks to simulate material that has been through a weld pass cycle. ${ }^{9,10,11}$ Brittle-zone microstructures are created in sufficient bulk to develop reliable Charpy transition curves that represent the various microstructures identified within the $L B Z$ region.

The thermal history and consequent morphology of HAZ welds are extremely complex. Each individual weld pass produces a four-zone microstructural gradient depicted in Fig 1. The coarse-grain HAZ (CGHAZ), schematic (D), immediately adjacent to the 
fusion line, consists of enlarged prior-austenite grains from the subsequent weld pass that grow rapidly due to being at a temperature close to the melting point. Upon cooling, the prior austenite can transform to martensite or a lower bainite/martensite mix, depending on the carbon equivalent (CE) of the base metal. At slow cooling rates, lowCE steels will transform to a lower-toughness microstructure, pearlite and/or upper bainite. With low $C E$, the cooling rate must be quite rapid to form martensite and lower bainite. Lower bainite and/or martensitic steel is more brittle as cooled, but these microstructures are converted to high-toughness steel after PWHT. The second zone, finegrain HAZ (FGHAZ), schematic (C), from the fusion line in Fig. 1, is fine-grain prior austenite resulting from slower austenitic grain growth at lower temperatures. The third zone, intercritical, coarse-grain HAZ (ICCGHAZ), schematic (B), is material heated into the $A_{c 3}$ and $A_{c 1}$ (intercritical) transformation zone. $A$ mixture of ferrite and austenite has precipitated along prior-austenite grain boundaries, which embrittles the material in this local region upon cooling to room temperature. ${ }^{9,10}$ These small volumes of material, ICCGHAZ, have been identified as the LBZ trigger-point locations. It is understood that LBZ material is created by the reheating of coarse-grain prior austenite from the subsequent weld passes that are adjacent to the fusion line. It therefore follows that there can be an appreciable amount of coarse-grain prior austenite along a fusion line that is not brittle crack initiation material. The fourth zone is the subcritically reheated coarsegrain zone of the (CGHAZ), which undergoes very little changed property.

The fundamental laboratory studies on LBZs usually produce ICCGHAZ material in bulk using electrical-resistance heating in a weld-cycle-simulation machine such as a Gleeble. It should be noted that some of the data sources reviewed had unintentionally produced damaged material, giving misleading results. It has been perhaps accurately noted that the temperature adjacent to the fusion line can approach $1590^{\circ} \mathrm{C}$ during a weld pass. The assumption that prior-austenite microstructures can be developed in simulation using such a temperature can too easily result in what is known as "burned steel." Steel can be burned when heating and holding at a temperature above $1260^{\circ} \mathrm{C}$ $\left(2300^{\circ} \mathrm{F}\right)$. Burned steel is irrecoverably-damaged steel, usable only as remelt stock. However, data reported from destroyed steel occasionally finds its way into the literature. An interesting outcome of the fundamental studies on microalloyed steels has 
or

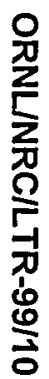

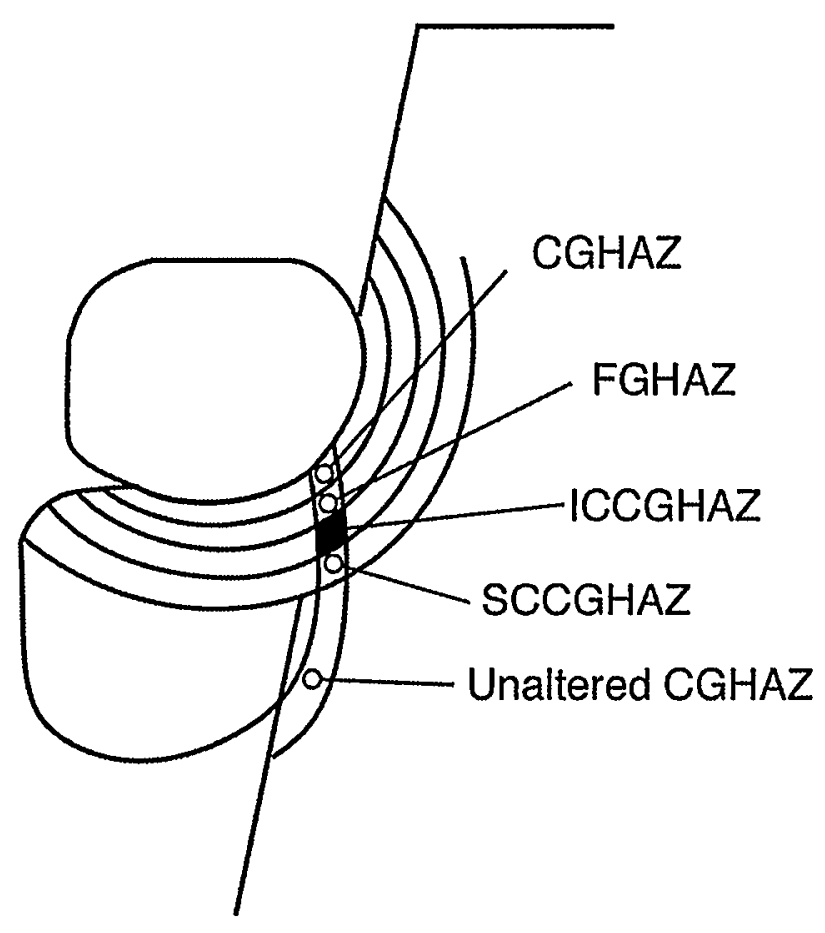

C

A

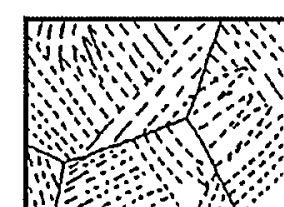

B
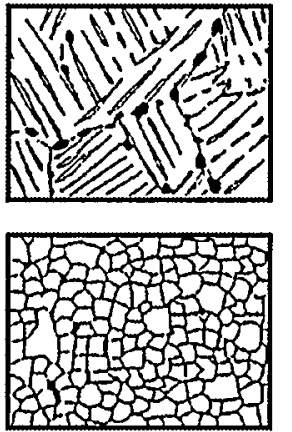

D

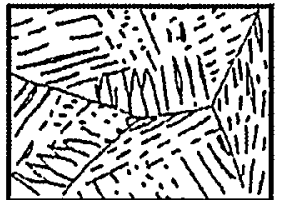

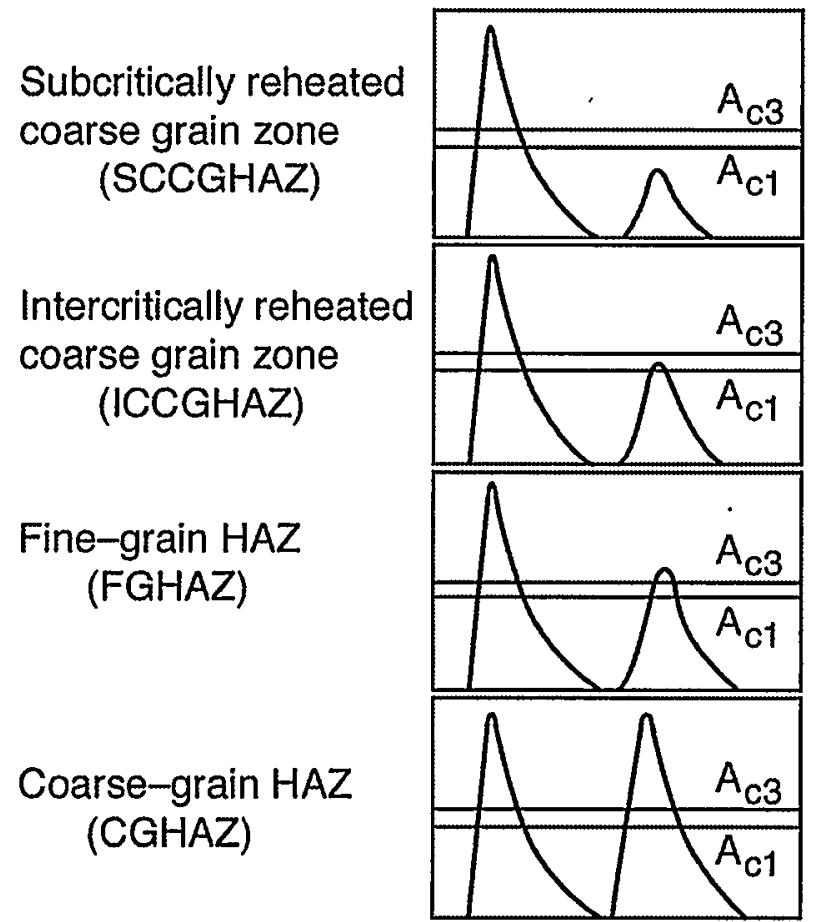

Figure 1. Schematic representation of microstructures local to the HAZ of multipass welds. 
been the demonstration that ICCGHAZ microstructures can cause about a 15 to $20^{\circ} \mathrm{C}$ transition-temperature increase over that of unsensitized material. ${ }^{10}$ When these same materials undergo PWHT at $450^{\circ} \mathrm{C}\left(842^{\circ} \mathrm{F}\right)$, the fracture toughness of ICCGHAZ material is restored, and in some cases is slightly improved over that of the unsensitized condition.

\section{Assessment of Commonality}

The paradoxical feature of the LBZ problem is that brittle cleavage fractures have only been encountered in CTOD tests made with three-point bend specimens. There have been no reports of offshore platforms suffering failures or damage resulting from LBZs. ${ }^{1}$ Hence, the extensive research work and material-qualification testing reported in the literature has provided answers that are in search of a problem. Nevertheless, cleavage trigger sources are considered dangerous when they occur in strain-rate-sensitive steels, and all failure-critical components deserve serious consideration.

Both offshore-platform welds and RPV weldments are multipass. Welds in offshore structures are principally shielded metal-arc welds (SMAWs), ${ }^{3}$ while RPV weldments are principally submerged arc welds (SAWs). The heat input is greater in the SAW process that can promote the development of coarse prior-austenite grains.

Transformation properties differ significantly between microalloyed steels and RPV steels. The CE is important from the standpoint of the transformation products formed on cooldown. Several important alloying elements contribute to $C E$, as indicated from the following equation: ${ }^{12}$

$$
\mathrm{CE}=\mathrm{C}+\frac{\mathrm{Mn}}{6}+\frac{\mathrm{Cu}+\mathrm{Ni}}{15}+\frac{\mathrm{Mo}+\mathrm{V}+\mathrm{Cr}}{5}
$$

The CE controls austenite stability and hence promotes transformation to lowtemperature transformation constituents, such as lower bainite and martensite. 
The typical CE in low-carbon microalloyed steel is about 0.37 ; the typical RPV steel has $\mathrm{CE}$ of about 0.62 . Hence, the cooling rate after each weld pass is more critical in the low-CE steels. Shielded metal-arc welding is performed in offshore structures because of the lower heat input and consequent faster cooling rate. Increased CE generally decreases weldability due to increased propensity for cracking. The transformation products tend to become brittle as cooled. However, postweld tempering converts the brittle microstructures into a steel with superior fracture-toughness properties. Tempering also improves fracture toughness of microalloyed steels, but this obvious remedy would eliminate much of the economic gain from their use in an as-welded condition.

Another important factor is service condition. Offshore platforms are expected to function at ambient temperatures down to $-40^{\circ} \mathrm{C}$. These low service temperatures do not alter the basic metallurgical condition of the steel. LBZ tests have produced crack initiation at test temperatures typically between -10 and $-60^{\circ} \mathrm{C}$. Had the CTOD testing been performed at room temperature, this very likely would have been within the upper-shelf temperature range for the embrittled LBZ materials and LBZ failures might not have been encountered. Cleavage crack initiation would have been replaced with ductile tearing. On the other hand, RPV steels operate between room temperature and $288^{\circ} \mathrm{C}$ $\left(550^{\circ} \mathrm{F}\right)$. Hence, a case has not been clearly made for the classical LBZ embrittlement model of microalloyed steels to apply to the RPV applications where service temperatures are not low. However, if end-of-life annealing were used, the service temperature cycle could include a 168 -h excursion to $482^{\circ} \mathrm{C}\left(900^{\circ} \mathrm{F}\right)$ for a one-time cycle. Therefore, the concern for grain coarsening in RPV welds arises from the potential for metallurgical degradation by temper embrittlement. Only the HAZs are at issue because RPV steel plate and forgings usually have fine prior-austenite grains, and as a consequence, the base plate materials are not considered to be vulnerable to temper embrittlement.

\section{LBZ in RPV Steels}

The temper-embrittlement susceptibility of grain-coarsened RPV steels was clearly demonstrated in work at AEA-Technology, Harwell, United Kingdom. ${ }^{13}$ Eleven laboratory heats of steel with typical RPV chemistry were made, and three of these with varied 
copper and phosphorus contents were selected for temper-embrittlement studies. The sensitivity to embrittlement was enhanced by heat treating to obtain huge prioraustenite grain size (about 0 to 1, ASTM Standard E 112). The austenitizing temperature was $1200^{\circ} \mathrm{C}\left(2200^{\circ} \mathrm{F}\right)$ with a 30 -min soak followed by an oil quench. All were given PWHT at $615^{\circ} \mathrm{C}\left(1140^{\circ} \mathrm{F}\right)$ with a 24-h soak, again followed by an oil quench. In contrast, coarse grains in offshore-structure LBZ studies were about 4 to 5 ASTM size. The AEA temper-embrittlement aging was $450^{\circ} \mathrm{C}\left(840^{\circ} \mathrm{F}\right)$ for $2000 \mathrm{~h}$ to be fully aged in order to maximize the degree of embrittlement obtainable. A second aging cycle was $475^{\circ} \mathrm{C}\left(890^{\circ} \mathrm{F}\right)$ to simulate an end-of-life recovery anneal cycle. One other exposure was irradiation to $12.2 \mathrm{mdpa}$ damage, presumably at $288^{\circ} \mathrm{C}\left(550^{\circ} \mathrm{F}\right)$. Table 1 is a condensed representation of the AEA results. It is important to keep in mind that $\Delta T_{0}$ from temper embrittlement is extremely grain size dependent, and with 0 to 1 grains, these results in Table 1 do not truly represent the coarse grain situation in RPV welds.

\section{ORNL Evaluation Followup}

Five commercially produced RPV steels were selected for the Heavy-Section Steel Irradiation (HSSI) evaluation program. Selection was based on the reported chemical elements shown in Table 2. An objective was to include at least one material with a

Table 1. Midtransition temperatures and shifts measured by AEA with CVN specimens

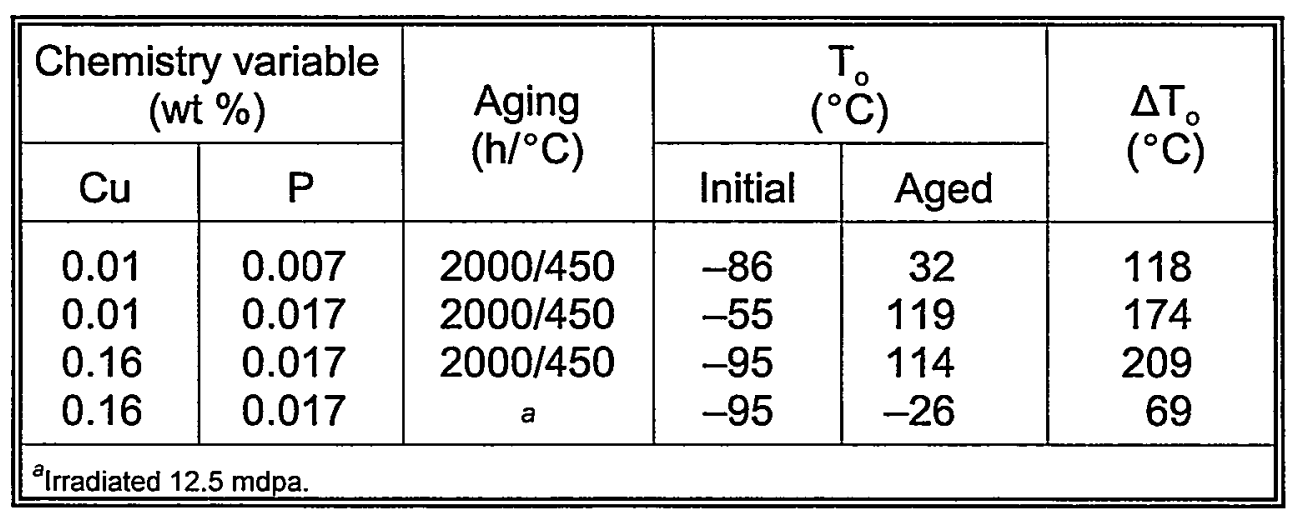


Table 2. Commercial materials selected

\begin{tabular}{||l|l|c|c|c|c||}
\hline \multirow{2}{*}{ Material } & \multirow{2}{*}{ Code } & \multicolumn{4}{|c||}{$\begin{array}{c}\text { Content } \\
(\text { wt \%) }\end{array}$} \\
\cline { 3 - 6 } & & $\mathrm{P}$ & $\mathrm{Ni}$ & $\mathrm{S}$ & $\mathrm{Cu}$ \\
\hline A 302 grade B & Maine Yankee & 0.015 & 0.2 & 0.017 & 0.14 \\
A 508 class 2 & Midland & 0.010 & 0.76 & 0.015 & 0.02 \\
Modified A 302 grade B & GE (Z5) & 0.016 & 0.62 & 0.015 & 0.17 \\
Modified A 302 grade B & GE (Z7) & 0.007 & 0.53 & 0.014 & 0.16 \\
A 533 grade B & HSST Plate 01 & 0.018 & 0.75 & 0.013 & 0.18 \\
\hline
\end{tabular}

phosphorus level as high as the material used in the AEA-Technology experiment (Table 1). High copper, by the AEA definition, is almost always present in the commercial steels. The high phosphorus, on the other hand, was not easily obtained (see Fig. 2). ${ }^{14}$

Confirming chemical analyses and tensile properties were obtained during the course of the present investigation, and these properties are reported along with the as-received values in Table 3. The initially reported chemistries were not entirely reliable, as can be

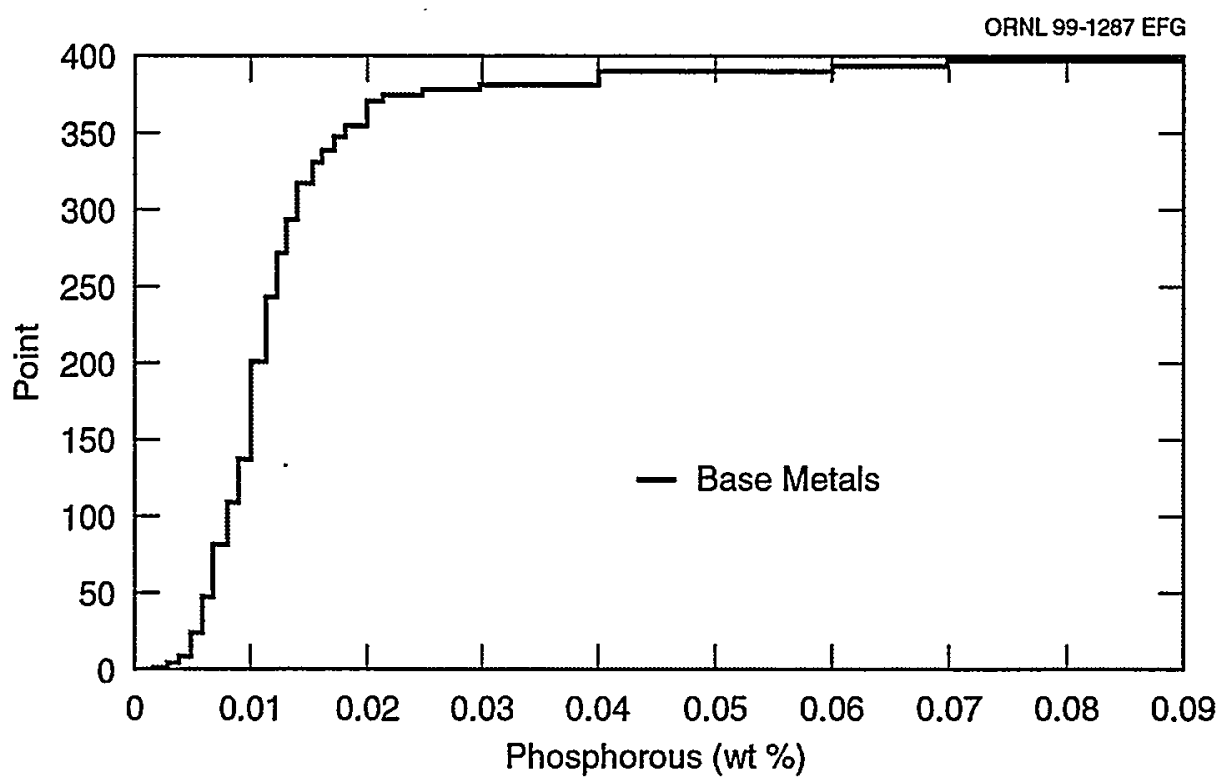

Figure 2. Cumulative number of chemical samplings made on RPV base metals vs the phosphorus content. 
Table 3. Summary of chemical analyses

\begin{tabular}{|c|c|c|c|c|c|c|c|c|c|c|c|c|c|c|}
\hline \multirow{2}{*}{ Material } & \multirow{2}{*}{ Condition $^{a}$} & \multicolumn{13}{|c|}{$\begin{array}{l}\text { Composition } \\
\text { (wt \%) }\end{array}$} \\
\hline & & C & $\mathrm{Mn}$ & $\mathrm{P}$ & $S$ & $\mathrm{Si}$ & $\mathrm{Ni}$ & $\mathrm{Cr}$ & Mo & V & $\mathrm{Nb}$ & $\mathrm{Cu}$ & As & Sn \\
\hline $\begin{array}{l}\text { A } 508 \\
\text { class } 2\end{array}$ & $\begin{array}{c}\text { AR } \\
\text { AEA } \\
\text { AS }\end{array}$ & $\begin{array}{l}0.20 \\
0.22 \\
0.22\end{array}$ & $\begin{array}{l}0.63 \\
1.04 \\
0.66\end{array}$ & $\begin{array}{l}0.010 \\
0.013 \\
0.013\end{array}$ & $\begin{array}{l}0.015 \\
0.010 \\
0.009\end{array}$ & $\begin{array}{l}0.19 \\
0.28 \\
0.27\end{array}$ & $\begin{array}{l}0.76 \\
0.73 \\
0.71\end{array}$ & $\begin{array}{l}0.37 \\
0.21 \\
0.34\end{array}$ & $\begin{array}{l}0.60 \\
0.57 \\
0.58\end{array}$ & $\begin{array}{c}<0.01 \\
0.002 \\
0.002\end{array}$ & $\begin{array}{l}\overline{0.004} \\
0.003\end{array}$ & $\begin{array}{l}0.02 \\
0.05 \\
0.05\end{array}$ & $\begin{array}{c}<0.01 \\
0.015 \\
0.015\end{array}$ & $\begin{array}{c}<0.01 \\
0.006 \\
0.006\end{array}$ \\
\hline $\begin{array}{l}\text { Mod } \\
\text { A } 302 \text { B }\end{array}$ & $\begin{array}{c}\text { AR } \\
\text { AEA } \\
A S\end{array}$ & $\begin{array}{l}0.16 \\
0.20 \\
0.19\end{array}$ & $\begin{array}{l}1.27 \\
1.12 \\
1.10\end{array}$ & $\begin{array}{l}0.014 \\
0.015 \\
0.016\end{array}$ & $\begin{array}{l}0.015 \\
0.018 \\
0.017\end{array}$ & $\begin{array}{l}0.17 \\
0.19 \\
0.19\end{array}$ & $\begin{array}{l}0.62 \\
0.61 \\
0.54\end{array}$ & $\begin{array}{l}0.10 \\
0.09 \\
0.09\end{array}$ & $\begin{array}{l}0.50 \\
0.47 \\
0.46\end{array}$ & $\begin{array}{l}0.002 \\
0.003 \\
0.003\end{array}$ & $\begin{array}{l}0.004 \\
0.005 \\
0.003\end{array}$ & $\begin{array}{l}0.17 \\
0.18 \\
0.19\end{array}$ & $\begin{array}{l}0.013 \\
0.018 \\
0.017\end{array}$ & $\begin{array}{l}0.017 \\
0.016 \\
0.015\end{array}$ \\
\hline $\begin{array}{l}\text { Mod } \\
\text { A } 302 \text { B }\end{array}$ & $\begin{array}{c}\text { AR } \\
\text { AEA } \\
\text { AS }\end{array}$ & $\begin{array}{l}0.26 \\
0.25 \\
0.27\end{array}$ & $\begin{array}{l}1.47 \\
1.42 \\
1.42\end{array}$ & $\begin{array}{l}0.007 \\
0.010 \\
0.011\end{array}$ & $\begin{array}{l}0.014 \\
0.013 \\
0.016\end{array}$ & $\begin{array}{l}0.15 \\
0.18 \\
0.18\end{array}$ & $\begin{array}{l}0.53 \\
0.55 \\
0.49\end{array}$ & $\begin{array}{l}0.09 \\
0.09 \\
0.09\end{array}$ & $\begin{array}{l}0.52 \\
0.48 \\
0.50\end{array}$ & $\begin{array}{l}0.002 \\
0.002 \\
0.002\end{array}$ & $\begin{array}{l}0.003 \\
0.004 \\
0.004\end{array}$ & $\begin{array}{l}0.16 \\
0.17 \\
0.19\end{array}$ & $\begin{array}{l}0.014 \\
0.021 \\
0.021\end{array}$ & $\begin{array}{l}0.018 \\
0.015 \\
0.015\end{array}$ \\
\hline
\end{tabular}

\begin{tabular}{|c|c|c|c|c|c|}
\hline \multirow{4}{*}{ 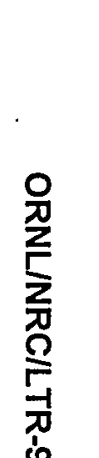 } & \multicolumn{5}{|c|}{ As-received tensile properties } \\
\hline & \multirow{2}{*}{ Material } & \multicolumn{2}{|c|}{ Yield strength } & \multicolumn{2}{|c|}{ Tensile strength } \\
\hline & & (MPa) & (ksi) & (MPa) & (ksi) \\
\hline & $\begin{array}{l}\text { A } 302 \text { B } \\
\text { A } 508 \text { class } 2 \\
\text { A } 533 \text { grade B } \\
\text { Mod A } 302 \text { B Z5 } \\
\text { Mod A } 302 \text { B Z7 }\end{array}$ & $\begin{array}{l}538 \\
394 \\
470 \\
400 \\
472\end{array}$ & $\begin{array}{l}78.1 \\
57.1 \\
68.2 \\
58.1 \\
68.5\end{array}$ & $\begin{array}{l}689 \\
569 \\
620 \\
538 \\
632\end{array}$ & $\begin{array}{c}100.1 \\
82.6 \\
89.9 \\
78.1 \\
91.7\end{array}$ \\
\hline
\end{tabular}


seen. One material, A 302 grade B, received in the as-normalized condition, was not available in the heat-treated condition desired. Consequently, the normalized microstructure was converted into a quenched-and-tempered product using the heattreatment cycles summarized in Table 4.

The cycles in Table 4 simulated the heat treatment reported on the low-phosphorus modified A 302 grade B steel listed in Table 2. This particular modified A 302 grade $B(Z 7)$ came from a commercial reactor nozzle cutout. The end result was suitable from a mechanical-properties standpoint, but it was later determined that the retreated A 302 grade B quenched-and-tempered microstructure had a prior-austenite grain size of ASTM 5, which was large in comparison to the other commercially made steels (Table 5).

Table 4. Heat-treatment cycles

\begin{tabular}{||l|c|c|l||}
\hline Treatment & $\begin{array}{c}\text { Temperature } \\
\left({ }^{\circ} \mathrm{F}\right)\end{array}$ & $\begin{array}{c}\text { Time } \\
(\mathrm{h})\end{array}$ & Quench \\
\hline Austenitize & 1700 & 6.5 & Water \\
Austenitize & 1625 & 6.5 & Water \\
Temper & 1200 & 6.5 & Water \\
Temper & 1125 & 6.5 & Water \\
\hline
\end{tabular}

Table 5. Grain sizes of the commercially made RPV base metal in their as-received condition

\begin{tabular}{|c|c|c|}
\hline Material & $\begin{array}{c}\text { Size by } \\
\text { E } 112\end{array}$ & $\begin{array}{l}\text { Average grain } \\
\text { diameter } \\
(\mu \mathrm{m})\end{array}$ \\
\hline $\begin{array}{l}\text { A } 302 \text { grade } B^{a} \\
\text { A } 508 \text { class } 2 \\
\text { A } 533 \text { grade B } \\
\text { Mod A } 302 \text { grade B Z5 } \\
\text { Mod A } 302 \text { grade B Z7 }\end{array}$ & $\begin{array}{c}5 \\
8 \\
8.5 \\
10 \\
9\end{array}$ & $\begin{array}{l}65 \\
22 \\
19 \\
11 \\
16\end{array}$ \\
\hline
\end{tabular}




\section{Program Plan}

The general plan to evaluate LBZ potential in RPV welds was structured to be in three phases, starting with the AEA-Technology large grain concept with the difference that commercially produced RPV steels were used. All three phases are defined as follows.

Phase I-Repeat the AEA austenitization and temper-embrittlement aging protocol (namely, temper-embrittlement cycles), using commercial steels.

1. Age $2000 \mathrm{~h}$ at $450^{\circ} \mathrm{C}\left(840^{\circ} \mathrm{F}\right)$.

2. Age $168 \mathrm{~h}$ at $490^{\circ} \mathrm{C}\left(914^{\circ} \mathrm{F}\right)$.

Phase II-Use a simulated SAW cycle to develop prior-austenite grains of ASTM 4 to 5. Then apply the AEA-Technology aging protocol.

1. Age $2000 \mathrm{~h}$ at $450^{\circ} \mathrm{C}\left(840^{\circ} \mathrm{F}\right)$.

2. Age $168 \mathrm{~h}$ at $450^{\circ} \mathrm{C}\left(840^{\circ} \mathrm{F}\right)$.

Phase III-Expand the aging-cycle evaluations starting with the simulated weld cycle austenitization used in Phase II.

1. $168 \mathrm{~h}$ at $482^{\circ} \mathrm{C}\left(900^{\circ} \mathrm{F}\right)$.

2. $168 \mathrm{~h}$ at $399^{\circ} \mathrm{C}\left(750^{\circ} \mathrm{F}\right)$.

3. Irradiate to $1 \times 10^{19} \mathrm{n} / \mathrm{cm}^{2}\left(>1 \mathrm{MeV}\right.$ at $\left.288^{\circ} \mathrm{C}\right)$.

4. Irradiate to $1 \times 10^{19} \mathrm{n} / \mathrm{cm}^{2}$, then age $168 \mathrm{~h}$ at $450^{\circ} \mathrm{C}$.

5. Age in air at $288^{\circ} \mathrm{C}\left(550^{\circ} \mathrm{F}\right)$.

Not mentioned in the above plan are the additions of baseline CVN data generated to provide the unaged baseline information needed to quantify transition-temperature shifts and to supplement the metallurgical evaluations. Temper-embrittlement damage is evaluated by standard CVN specimen transition-curve shift. 


\section{Results}

Phase I-All of the commercially produced steels that were given the AEA-Technology austenitic cycle had microstructures ranging from tempered martensite to lower bainite. Grain size according to ASTM Standard E112 was generally between 0 and 00 , meaning that the typical austenite grain diameter was on the order of 360 to $500 \mu \mathrm{m}$ (Fig. 3). The microstructure after PWHT is represented by Fig. 4.

Transition-temperature CVN energy, $E_{J}$, data were least-squares fitted to the following hyperbolic tangent equation:

$$
E_{J}=A+B \tanh \left[\left(T-T_{0}\right) / C\right],
$$

where

$$
\begin{aligned}
A & =(U S E+L S E) / 2 \\
B & =(U S E-L S E) / 2 \\
C & =\text { width of the transition, } \\
T_{0} & =\text { midtransition temperature. }
\end{aligned}
$$

Parameter $T_{0}$ was selected to be the Charpy transition-curve temperature level of reference. $T_{0}$ is a point halfway between the lower-shelf energy (LSE) and upper-shelf Charpy energy (USE). This point was selected because it tends to be a position that is least affected by changes in curve shape. The LSE used in fitting data to Eq. (2) was held constant at $2.7 \mathrm{~J}$.

Table 6 lists the $T_{0}$ temperatures of the five commercial RPV steels in the as-received condition, both before and after embrittlement aging. These results can be compared with the embrittlement from AEA-Technology austenitizing cycles and aging, Table 1. As-received RPV steels with small grains on the order of ASTM 8 to 11 showed insignificant embrittlement. The A 302 grade B exception was caused by larger grains, on the order of 5 . 
ORNL 99-1288 EFG

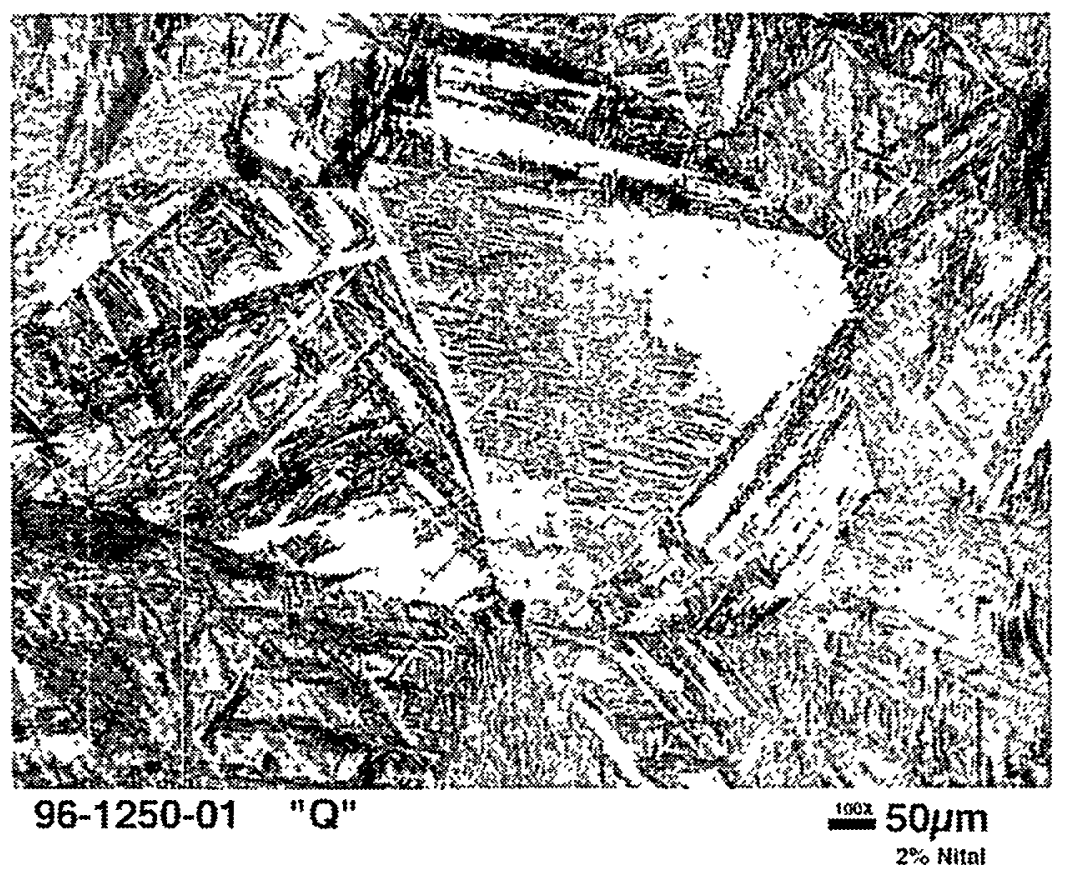

Figure 3. Example of the as oil-quenched microstructure after the AEA-Technology austenitization and quench cycle, A 533 grade B, 100x.

ORNL 99-1289 EFG

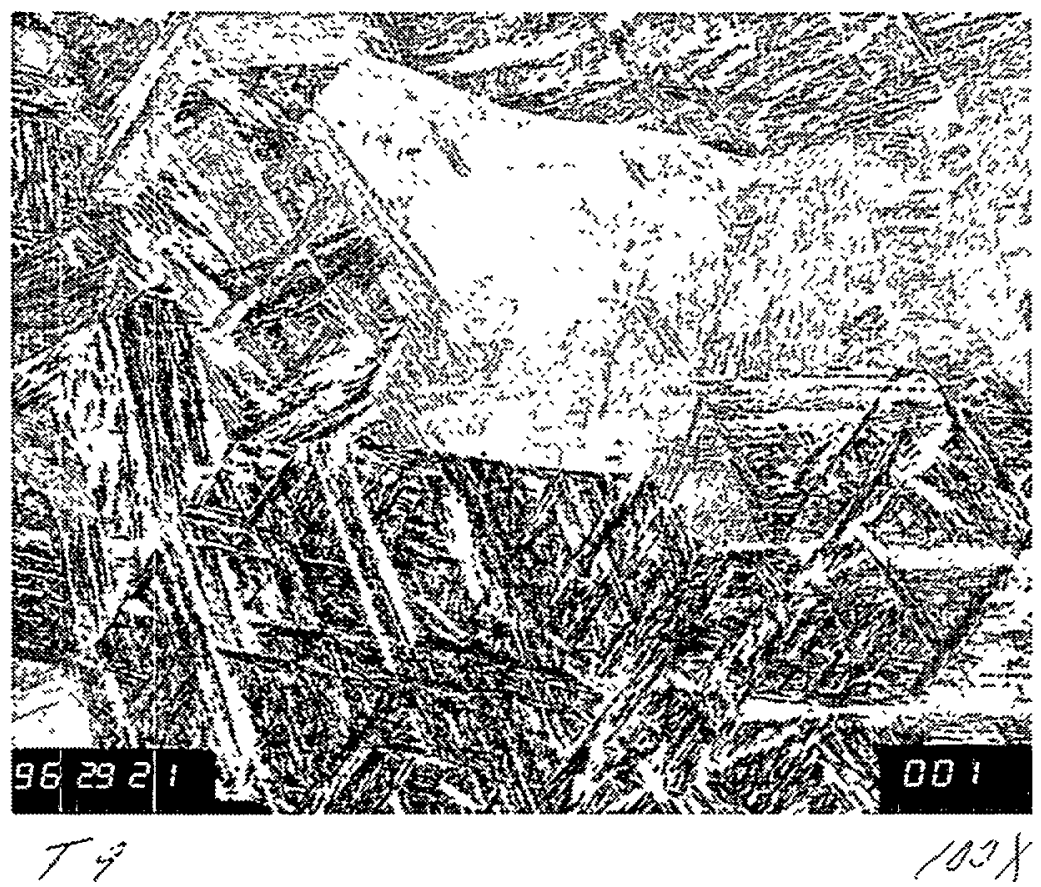

Figure 4. Example of the typical microstructure after the AEA-Technology austenitization and PWHT, A 533 grade $B, 100 x$. 
Table 6. Revisit of AEA cycles used on five commercially made RPV steels; Phase I transition temperatures, $\mathrm{T}_{\mathrm{o}}\left({ }^{\circ} \mathrm{C}\right)$

\begin{tabular}{|c|c|c|c|c|c|c|c|}
\hline \multirow[b]{2}{*}{ Condition } & \multirow{2}{*}{$\begin{array}{c}\text { Aging } \\
\text { time } \\
\text { (h) }\end{array}$} & \multirow{2}{*}{$\begin{array}{c}\text { Aging } \\
\text { temperature } \\
\left({ }^{\circ} \mathrm{C}\right)\end{array}$} & \multirow[b]{2}{*}{ A $302 B$} & \multirow[b]{2}{*}{ A 533 B } & \multirow{2}{*}{$\begin{array}{c}\text { A } 508 \\
\text { class } 2\end{array}$} & \multicolumn{2}{|c|}{ Modified A 302 B } \\
\hline & & & & & & $\begin{array}{c}\text { High } \\
\text { phosphorous }\end{array}$ & $\begin{array}{c}\text { Low } \\
\text { phosphorous }\end{array}$ \\
\hline $\begin{array}{l}\text { As received } \\
\text { As received } \\
\text { AEA austenitize }{ }^{a} \text { and } \mathrm{PWHT}^{b} \\
\text { AEA austenitize }{ }^{a} \text { and } \mathrm{PWHT}^{b} \\
\mathrm{AEA} \text { austenitize }{ }^{a} \text { and } \mathrm{PWHT}^{b}\end{array}$ & $\begin{array}{l}\text { Initial } \\
2000 \\
\text { Initial } \\
2000 \\
168\end{array}$ & $\begin{array}{l}- \\
450 \\
\frac{-}{450} \\
490\end{array}$ & $\begin{array}{l}0 \\
64 \\
10 \\
45 \\
44\end{array}$ & $\begin{array}{r}20 \\
38 \\
-67 \\
78 \\
65\end{array}$ & $\begin{array}{r}0 \\
10 \\
4 \\
41 \\
16\end{array}$ & $\begin{array}{r}-9 \\
-4 \\
-23 \\
34 \\
16\end{array}$ & $\begin{array}{r}-9 \\
10 \\
-73 \\
42 \\
-3\end{array}$ \\
\hline
\end{tabular}


Focusing on the AEA austenization cycle data for $2000 \mathrm{~h}$ age at $450^{\circ} \mathrm{C}$, it appears that steels with the best initial fracture toughness (lowest $T_{0}$ temperatures) tend to have the greatest transition-temperature shift. Figure 5 illustrates this point. If the AEA-

Technology data from Table 1 are included, the extent to which copper and phosphorus seemed to control $\Delta T_{0}$ appears to be second-order when the results are viewed within the effect shown in Fig. 5.

The simulation of aging for $168 \mathrm{~h}$ at $490^{\circ} \mathrm{C}$ was almost as effective as the $2000 \mathrm{~h}$ at $450^{\circ} \mathrm{C}$ in some cases. This indicates that the aging rate is asymptotic. However, this should not be regarded as a firm observation because $\Delta T_{0}$ rate was not the subject of this work.

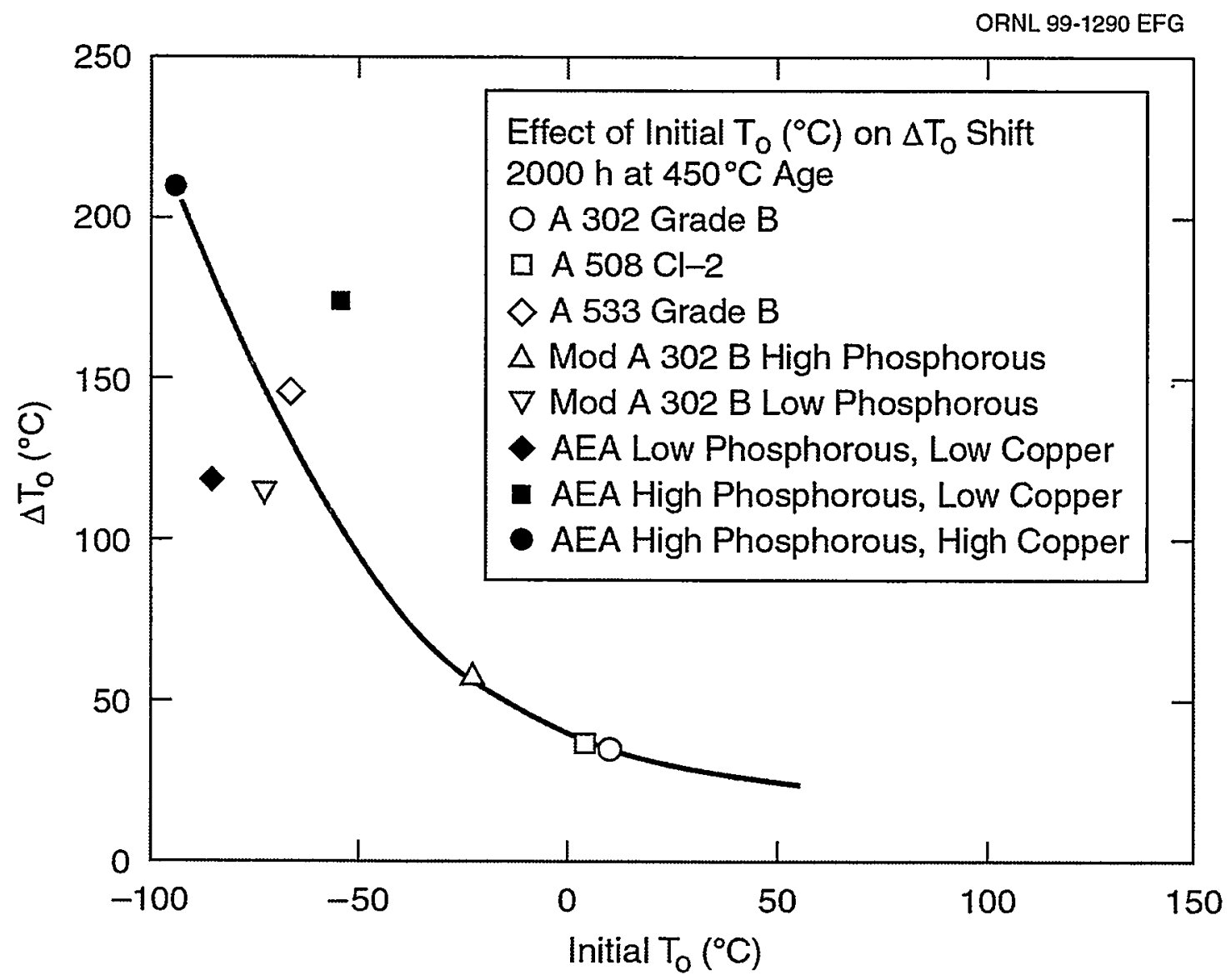

Figure 5. Relationship between initial $T_{0}$ temperature and $\Delta T_{0}$ after 2000-h aging at $450^{\circ} \mathrm{C}$. 
In summary, the results from the Phase I repeat of the AEA-Technology experiments using commercially made steels in most cases did not quite measure up to the $\Delta T$ damage level of the AEA-Technology experiments. The conversion to large prior-austenite grains by the AEA-Technology austenitizing treatment by itself did not always cause significant change in fracture toughness from the as-received fracture toughness. For example, comparing rows 1 and 3 in Table 6 , there were small increases in $T_{0}$ for two materials, while the other three changes in $T_{0}$ were negative, with two of these being substantial. The $\Delta T_{0}$ shift from the subsequent temper-embrittlement aging seems to be strongly influenced by the initial post-AEA austenitized $T_{0}$ values as shown in Fig. 5 . The grain-size dependence of $\Delta T_{0}$ on prior-austenite grain size was clearly demonstrated in four of the five materials tested and weakly demonstrated in the fifth. However, the grain sizes that resulted from the AEA austenitizing treatment are considerably larger than those expected in actual ICCGHAZ regions, suggesting that these Phase I results do not truly represent the coarse-grain situation that we wished to evaluate in commercial RPV welds.

Phases II and III-The electrical-resistance heating and cooling equipment (Gleeble) that is designed specifically for simulation of weld cycles was applied to austenization of the same five materials tested in Phase I. Because the intercritical reheating cycle, identified as the source of LBZ behavior in low-carbon microalloyed steels, was determined to be of no relevance to RPV steels, only a single simulation cycle was needed in the present experiment to simply create the simulated coarse prior-austenite grains in RPV HAZs. A report ${ }^{15}$ based on research funded by the NRC was used to decide upon the most appropriate thermal cycle. Peak temperature and time were selected to develop ASTM grain size in the range of 4 to 5 . The peak temperature was limited to $1260^{\circ} \mathrm{C}\left(2300^{\circ} \mathrm{F}\right)$, specifically to be below the burning temperature for steels of typical RPV chemistry. The thermal cycle used is shown in Fig. 6. Specimen blanks prepared for the Gleeble were cylindrical rods about $76 \mathrm{~mm}$ long and $14.35 \mathrm{~mm}$ in diameter ( 3 by 0.564 in.). About $5 \mathrm{~mm}$ ( $0.2 \mathrm{in}$.) of material at the center of each rod was determined to be representative of the weld cycle material. An example photomicrograph of the resulting microstructure appears in Fig. 7, showing a mixture of martensite and lower bainite. 


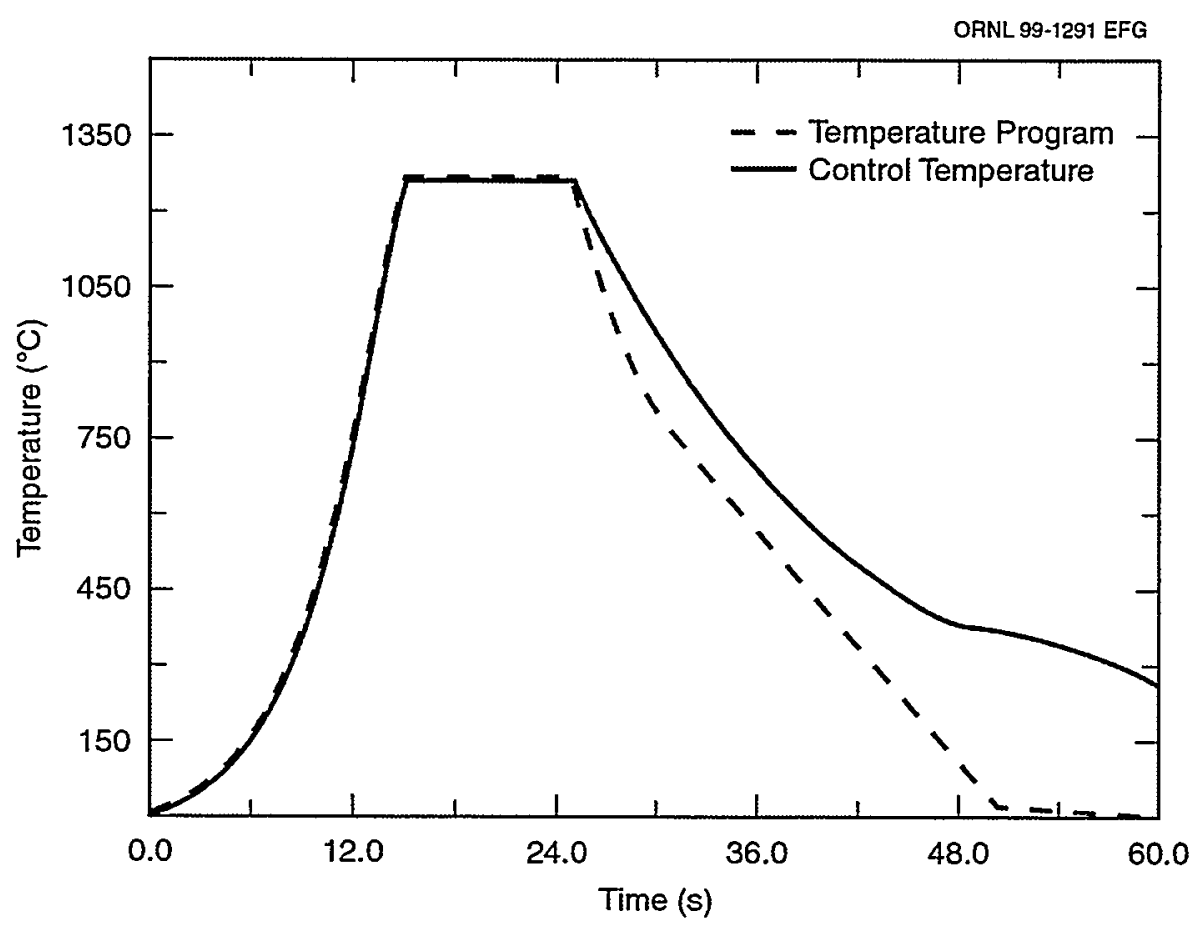

Figure 6. Gleeble-generated weld thermal cycle to develop ASTM 4.5 grain size.

ORNL 99-1292

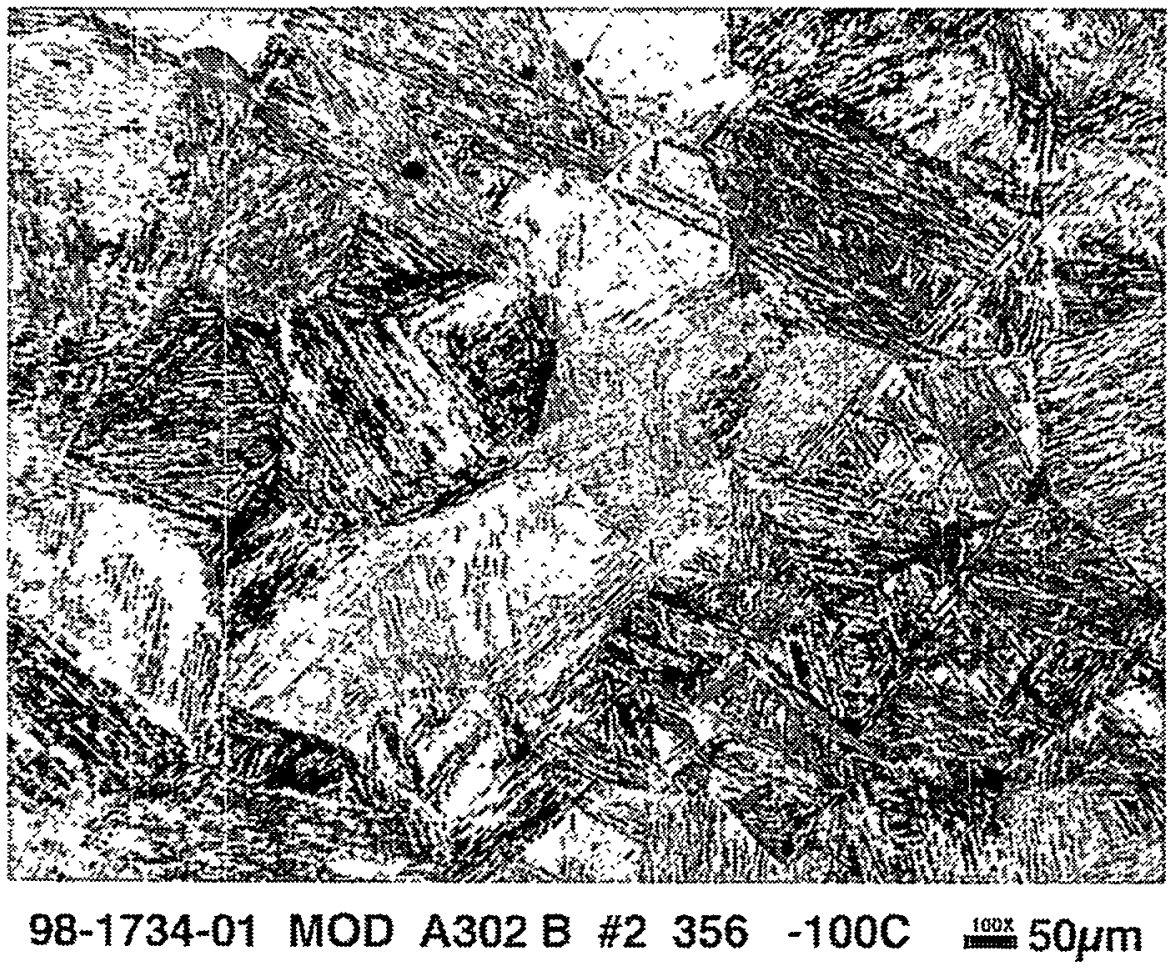

Figure 7. Photomicrograph of microstructure after Gleeble austenitization, high-phosphorus modified A 302 grade B, nital etch, 100x. 
Table 7 lists the Gleeble weld simulation and aging data developed to date: Phase II, on lines 1, 3, and 5, and part of Phase III on lines 2 and 4. The PWHT cycle used was identical to that used in the AEA-Technology simulation, namely, a 24-h soak time at $615^{\circ} \mathrm{C}\left(1140^{\circ} \mathrm{F}\right)$ followed by an oil quench. Note that the as-tempered fracture toughness reflects a favorable microstructural condition that in all probability resulted from the fast cooling of the weld cycle simulation. Aging time at $168 \mathrm{~h}$ represents the expected hold time that could be used in an RPV annealing procedure. There are three aging temperatures that represent the lowest to highest practical annealing temperatures that have been under consideration. At $399^{\circ} \mathrm{C}$, there appears to be no evidence of temper embrittlement in four materials. This could also be true for the highphosphorus modified A 302 grade B steel (Z5) that for a lack of sufficient material was not included in this aging exposure. Embrittlement develops and accelerates with temperatures between 450 and $482^{\circ} \mathrm{C}\left(842\right.$ and $\left.900^{\circ} \mathrm{F}\right)$. Hence, these two annealing conditions affect temper embrittlement damage, provided there is coarse-grain HAZ material. However, Fig. 8 shows that none of the transition-temperature end points, after annealing for $168 \mathrm{~h}$, exceeded room temperature. After $2000 \mathrm{~h}$ at $450^{\circ} \mathrm{C}$, only two of the five materials had $T_{0}$ temperatures that exceeded room temperature.

Table 7. Materials austenitized by Gleeble, PWHT, and aged commercially made RPV steels (Phase II and first part of Phase III combined)

\begin{tabular}{|c|c|c|c|c|c|c|c|}
\hline \multirow{3}{*}{$\begin{array}{l}\text { Austenitize } \\
\text { method }\end{array}$} & \multirow{3}{*}{$\begin{array}{c}\text { Aging } \\
\text { temperature } \\
\left({ }^{\circ} \mathrm{C}\right)\end{array}$} & \multirow{3}{*}{$\begin{array}{c}\text { Aging } \\
\text { time } \\
\text { (h) }\end{array}$} & \multicolumn{5}{|c|}{$\begin{array}{c}\text { Transition temperature, } T_{0} \\
\left({ }^{\circ} \mathrm{C}\right)\end{array}$} \\
\hline & & & \multirow{2}{*}{ A 302 B } & \multirow{2}{*}{ A 533 B } & \multirow{2}{*}{$\begin{array}{l}\text { A } 508 \\
\text { class } 2\end{array}$} & \multicolumn{2}{|c|}{$\begin{array}{r}\text { Modified } \\
\text { A } 302 \text { B }\end{array}$} \\
\hline & & & & & & High $\mathrm{P}^{a}$ & Low $\mathrm{P}$ \\
\hline Gleeble & Initial & 0 & -87 & -67.0 & -102 & - & -67 \\
\hline Gleeble & 399 & 168 & - & -67.1 & -98.6 & -89.4 & -71.1 \\
\hline Gleeble & 450 & 168 & -44 & -28 & -80 & - & -47 \\
\hline Gleeble & 482 & 168 & - & 7.4 & -72.6 & -47.4 & -33.6 \\
\hline Gleeble & 450 & 2000 & 43 & 66 & -46 & -14 & -4 \\
\hline
\end{tabular}


ORNL 99-1293 EFG

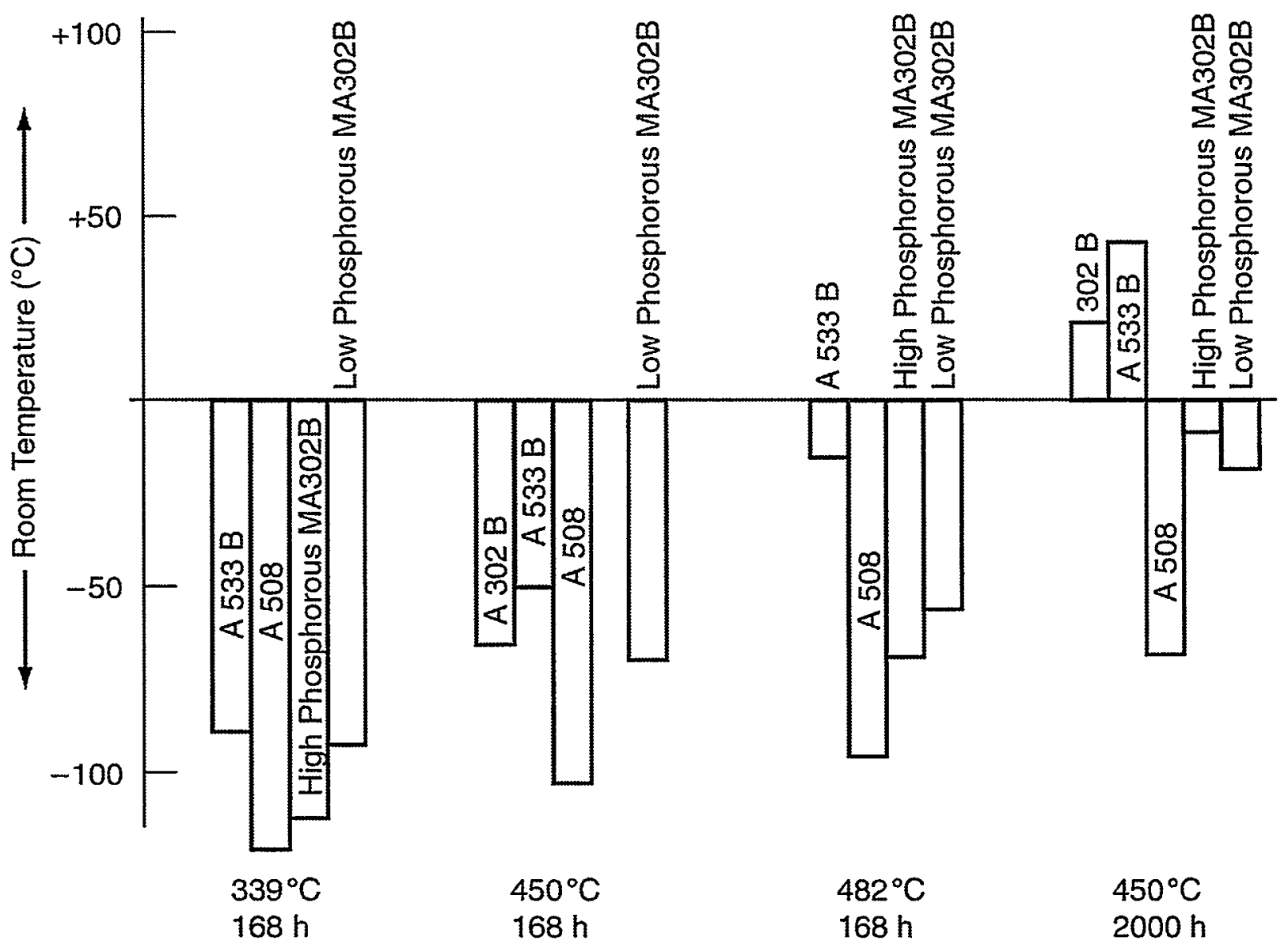

Figure 8. Position of $C V N T_{0}$ temperatures after aging $168 \mathrm{~h}$ at $399^{\circ} \mathrm{C}, 450^{\circ} \mathrm{C}$, and $482^{\circ} \mathrm{C}$ and $2000 \mathrm{~h}$ at $450^{\circ} \mathrm{C}$ (MA302B stands for modified A 302 grade B). 
Six commercial welds were examined for maximum grain size along the fusion line (Table 8). The results of this small sampling of actual RPV welds suggested that the presumed coarse-grain size and uniform distribution characteristics do not always exist. The coarse grains that could be found were much smaller than ASTM 4.5, and the percentage of coarse grain along all fusion lines was found to be very low. Example photomicrographs taken at selected large-grain locations are shown in the Appendix.

Table 8. Largest coarse-grain sizes found in HAZs of six commercially fabricated RPV welds

\begin{tabular}{||l|c||}
\hline \multicolumn{1}{|c|}{ Weld source } & $\begin{array}{c}\text { ASTM E 112 } \\
\text { grain size }\end{array}$ \\
\hline HSSI Fifth Irradiation Series, 72W & 6.5 \\
HSSI Fifth Irradiation Series, 73W & 9.0 \\
SNUPPS beltline & 7.5 \\
SNUPPS longitudinal & 7.5 \\
Midland beltline & 10 \\
Midland nozzle course & 6.5 \\
\hline
\end{tabular}

\section{Measurement of Element Diffusion to Grain Boundaries}

Measurement of element diffusion to grain boundaries was conducted as part of a collaboration with AEA-Technology. The segregation of critical elements to grain boundaries on four selected specimens was measured by scanning transmission electron microscopy. These results were then compared with theoretical calculations using the McLean model as well as the Murphy and Perks model. ${ }^{16}$ Experimental results are shown in Table 9. All specimens had been Gleeble austenitized to ASTM grain size of 4 to 5 , followed by PWHT at $615^{\circ} \mathrm{C}\left(1140^{\circ} \mathrm{F}\right)$ for $24 \mathrm{~h}$. The grain-boundary analyses also included $\mathrm{Cu}, \mathrm{Si}$, and $\mathrm{Cr}$; none of which were found to be involved in the segregation process. Measurement replication was four times, and in some cases the variability was huge. Phosphorous segregation to grain boundaries was also calculated. The McLean 
Table 9. Measured increased contents, percent increase of selected elements; grain boundary vs bulk contents

\begin{tabular}{|c|c|c|c|c|c|}
\hline \multirow{2}{*}{ Material } & \multirow{2}{*}{ Treatments } & \multicolumn{4}{|c|}{$\begin{array}{l}\text { Percent increase at } \\
\text { boundaries (at \%) }\end{array}$} \\
\hline & & $\mathrm{Mn}$ & Mo & $\mathrm{P}$ & $\mathrm{Ni}$ \\
\hline $\begin{array}{l}\text { Modified A } 302 \text { B } \\
\text { (low phosphorous) }\end{array}$ & $\begin{array}{l}\text { Gleeble austenitized and } \\
\text { PWHT (unaged) }\end{array}$ & 9 & 12 & 1 & 1 \\
\hline $\begin{array}{l}\text { Modified A } 302 \text { B } \\
\text { (low phosphorous) }\end{array}$ & $\begin{array}{l}\text { Gleeble austenitized and } \\
\text { PWHT (aged at } 450^{\circ} \mathrm{C} \text {, } \\
2000 \mathrm{~h} \text { ) }\end{array}$ & 19 & 16 & 10 & 1.5 \\
\hline $\begin{array}{l}\text { Modified A } 302 \text { B } \\
\text { (high phosphorous) }\end{array}$ & $\begin{array}{l}\text { Gleeble austenitized and } \\
\text { PWHT (aged at } 450^{\circ} \mathrm{C} \text {, } \\
2000 \mathrm{~h} \text { ) }\end{array}$ & 14 & 32 & 17 & 8 \\
\hline $\begin{array}{l}\text { A } 533 \text { grade B (high } \\
\text { phosphorous) }\end{array}$ & $\begin{array}{l}\text { Gleeble austenitized and } \\
\text { PWHT (aged at } 450^{\circ} \mathrm{C} \text {, } \\
2000 \mathrm{~h} \text { ) }\end{array}$ & 19 & 15 & 5 & 10 \\
\hline
\end{tabular}

equation reasonably predicted segregated concentrations of all the modified A $302 \mathrm{~B}$ specimens but overestimated the A 533 grade $B$ segregation. The problem could be that the bulk phosphorous given in Table 2 was used in the calculation, instead of the more recent phosphorous determinations that appear in Table 3.

The same Gleeble-austenitized and $450^{\circ} \mathrm{C}$ aged $A 533$ grade $B$ steel analyzed by AEA was also submitted to Auger analysis at ORNL. ${ }^{17}$ In this method, a fresh fracture surface is created under vacuum and analyzed. Part of the surface is intergranular, exposing the grain boundaries (GBs), as shown in Fig. 9, and the other part of the surface is transgranular (TG) cleavage. Bulk phosphorous was determined on cleavage surfaces and on grain boundaries after $10 \AA \AA$ were removed by sputtering (SP) (see Fig. 10). On average, the difference between bulk and GB phosphorous is a factor of 10. Additionally, intergranular fracture vanishes at upper-shelf test temperatures as seen, for example, in Fig. 11. 


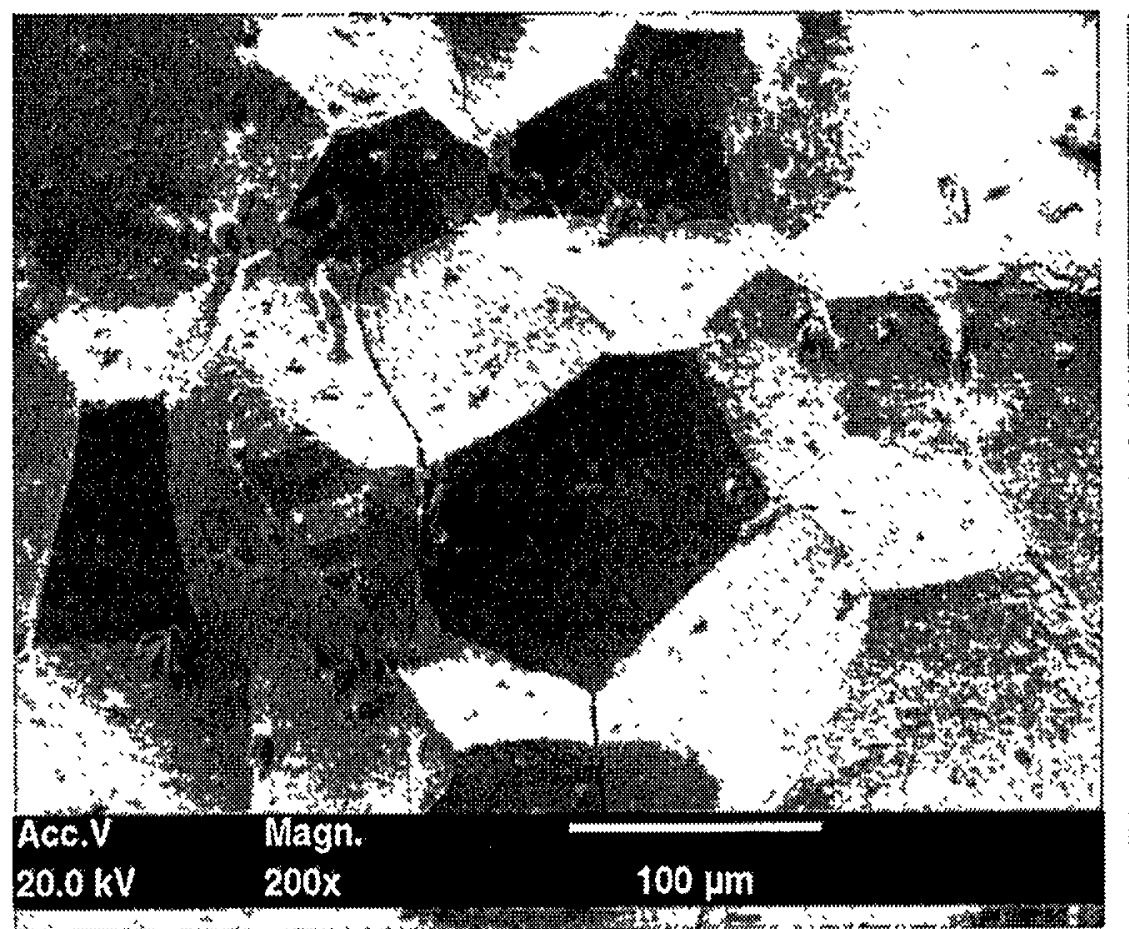

Modified A302 Grade B Low Phosphorus $200 x$
ORNL 99-1294 EFG

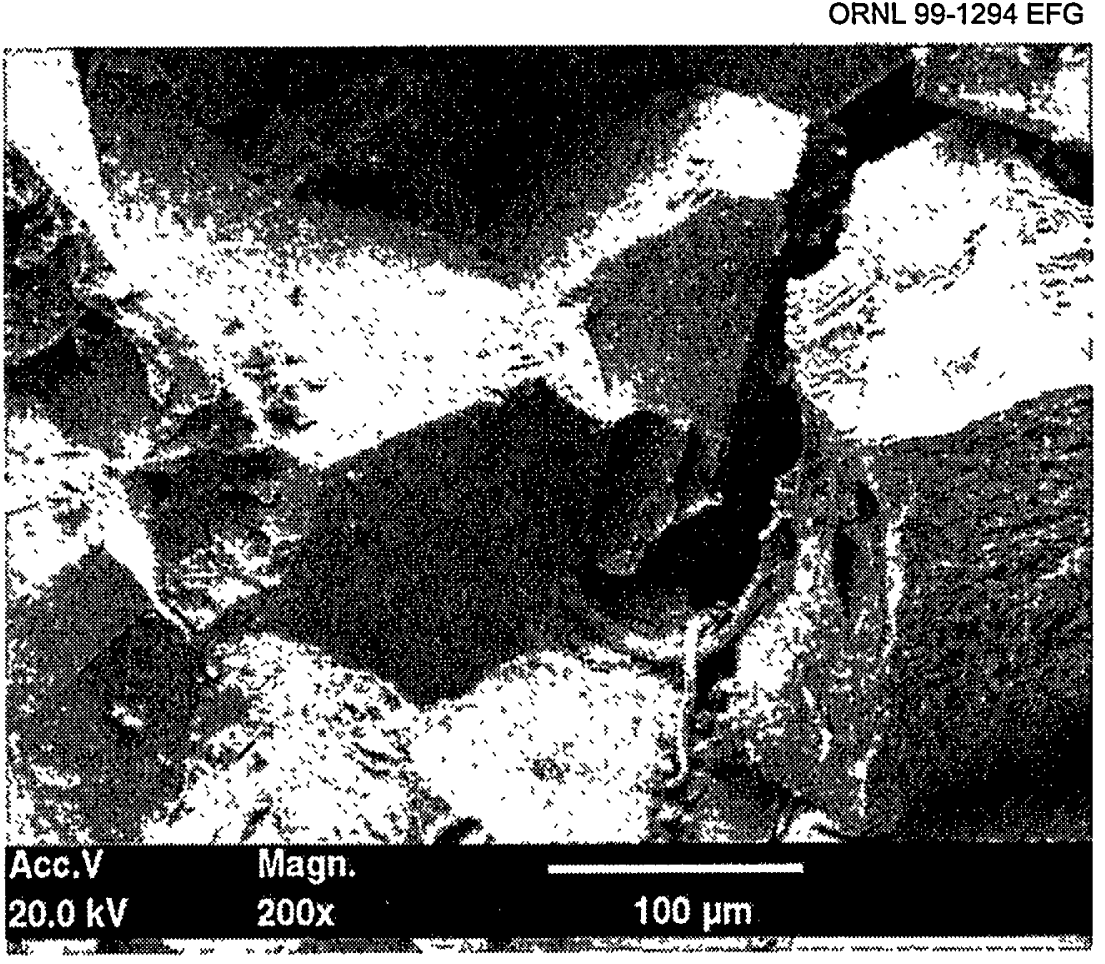

Modified A302 Grade B High Phosphorus $200 x$

Figure 9. Intergranular fracture of A 533 grade B steel after Gleeble austenitization, PWHT, and 200-h aging at $450^{\circ} \mathrm{C}$. Charpy lower shelf test temperature. 
Phosphorous Concentration (at. \%)

$\tilde{\AA}$

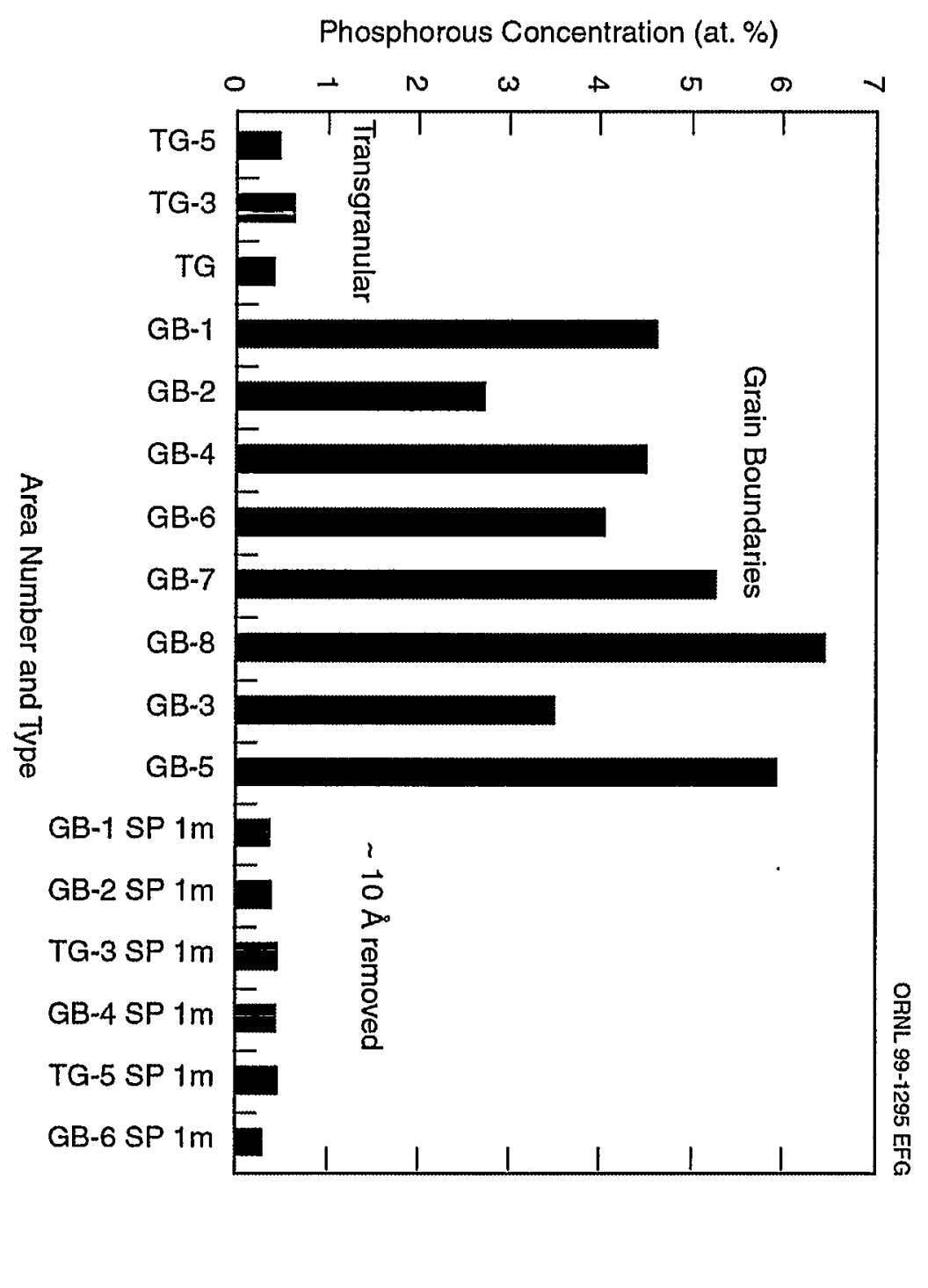



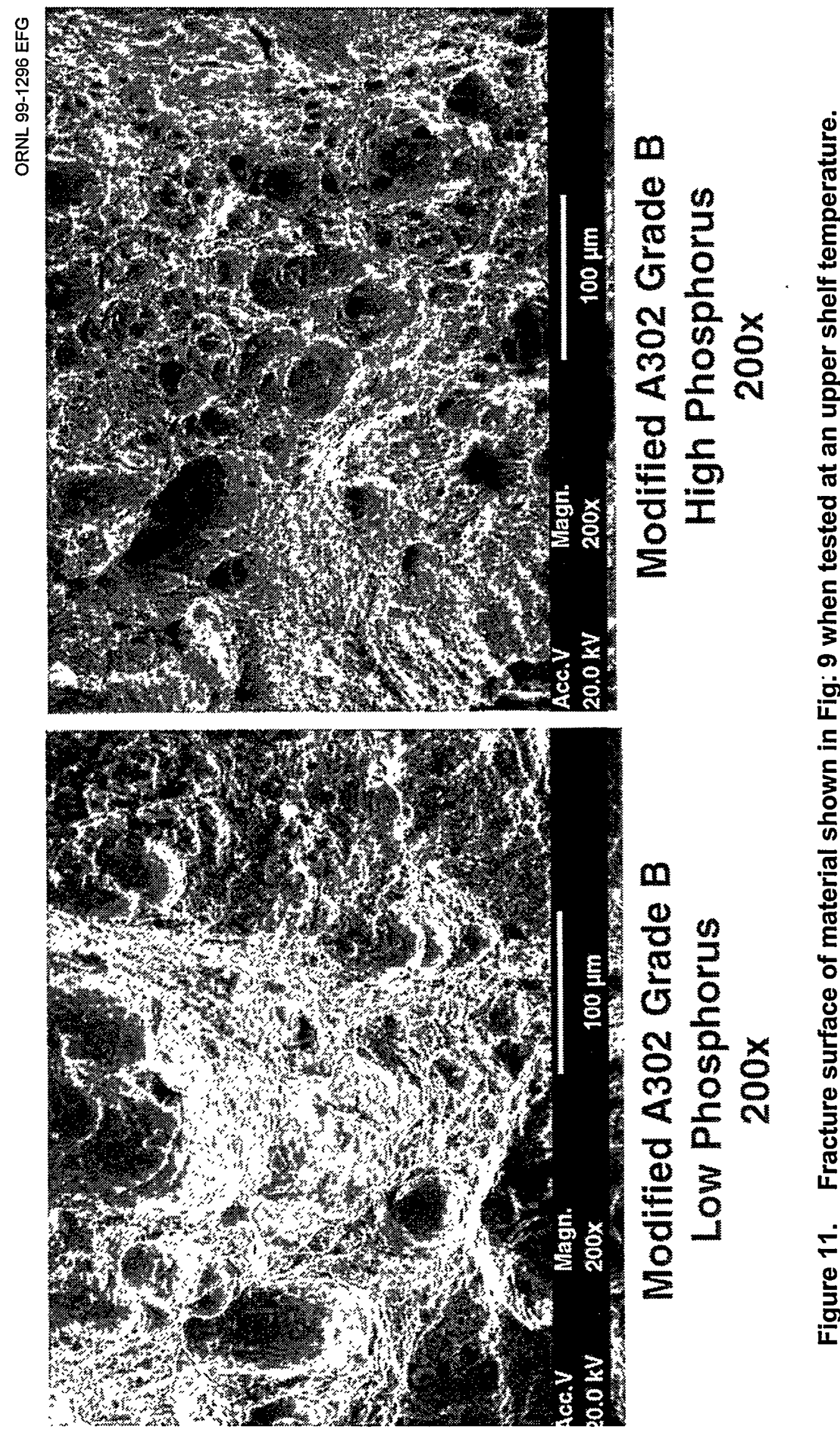

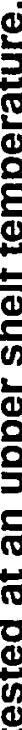

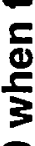

훔

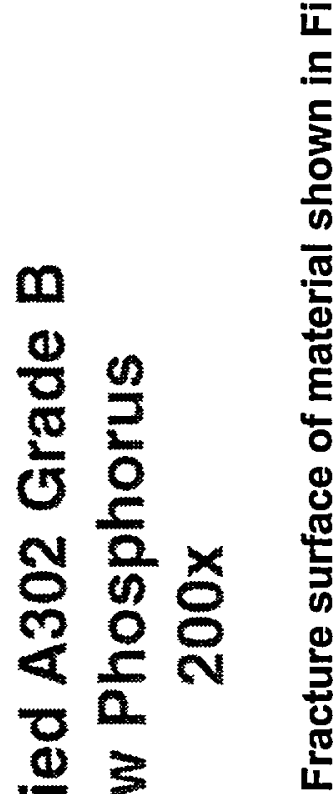




\section{Discussion}

Evaluations made from a literature search on LBZs in multipass weldments of lowcarbon microalloyed steels have revealed that the problem of LBZs, as described for microalloyed steels, does not transfer automatically to welds in RPVs. All of the published LBZ work addressed the problem associated with the welding of low-CE steels. The application is offshore structures for which operating temperatures can be as low as $-40^{\circ} \mathrm{C}$. Temperatures used in CTOD bend bar tests to find LBZs ranged from -10 to $-60^{\circ} \mathrm{C}$, which are well below temperatures of interest to RPV operations. PWHT can substantially alleviate LBZ effects in welds of microalloyed steels, ${ }^{4}$ but such a procedure is avoided if possible in offshore structures because of the difficulty and financial penalty to do so. All RPVs, on the other hand, are given PWHT. However, RPVs potentially could develop a brittle-zone problem because of a completely different embrittlement mechanism; namely, the susceptibility of RPV steels with enlarged prior-austenite grains to temper embrittlement.

Experiments at AEA-Technology have clearly demonstrated that steels with the typical RPV chemistry can be made to be highly sensitive to temper embrittlement provided the prior-austenite grain size is enlarged to more than $360 \mu \mathrm{m}$ in diameter. The SAW process used in RPV fabrication is a high-heat-input welding procedure, and grains of substantial enlargement would seem quite likely; more so than in offshore SMAW weldments. Hence, there was a need to pursue more information on temper embrittlement. The scope of interest was the temper-embrittlement properties of commercially made RPV steels and the influence of grain-size and thermal-cycle effects.

The objective of Phase I was to confirm the AEA-Technology findings, except in this case commercially made steels were used. This work clearly showed that the temper embrittlement seen with the AEA-Technology laboratory-made steels did in fact apply to the five selected commercially made steels. However, the $\Delta T_{0}$ magnitude was somewhat less. An interesting new observation was that $\Delta T_{0}$ due to embrittlement seemed to be strongly influenced by the initial $T_{0}$ temperature value. A material with extremely low initial $T_{0}$ temperature will tend to experience greater $\Delta T_{0}$. The phosphorus and copper 
concentrations do not seem as significant when compared with the influence of the initial transition temperature.

Phase II introduced an anticipated more-representative weld HAZ coarse grain size, as well as the heating and cooling rates of a typical weld pass. Both are important new and relevant variables. Most RPV steels have CE of about twice that of microalloyed steels. Consequently, the transformation products formed with the high cooling rates of a weld pass are favorable for the development of high fracture toughness, provided postweld stress relief tempering is used. All of the commercial steels had exceptionally good (low-temperature) preaged transition temperatures after simulated weld cycles. Given a $168-h$ anneal at $450^{\circ} \mathrm{C}$, the fracture toughness was degraded, but not to an extent that cancelled the fracture-toughness improvement from the austenitization and PWHT cycle.

Phase III expanded the study to look at other aging-condition variables. The austenitization, PWHT, and grain size are the same as in Phase II. Aging time is fixed at $168 \mathrm{~h}$, but aging temperature is varied. It appears that there can be a lower-bound aging temperature for temper embrittlement. At $399^{\circ} \mathrm{C}\left(750^{\circ} \mathrm{F}\right)$ there was no detectable temper embrittlement effect in any of the steels. At 450 and $482^{\circ} \mathrm{C}\left(842\right.$ and $\left.900^{\circ} \mathrm{F}\right)$, significant transition-temperature shifts could be seen. However, there were no postembrittlement (168 h) $\mathrm{T}_{\mathrm{o}}$ temperatures observed above room temperature.

The work in progress in Phase III will address the effects of irradiation and postirradiation annealing. The final issue to be determined is whether an RPV steel with demonstrated temper-embrittlement insensitivity at temperatures below $400^{\circ} \mathrm{C}$ can suffer embrittlement at $288^{\circ} \mathrm{C}$ when the thermal exposure is combined with neutron irradiation or when irradiation is followed by postirradiation heat treatments at $454^{\circ} \mathrm{C}$ for $168 \mathrm{~h}$, intended to recover fracture toughness.

It is important to point out that the $T_{0}$ temperature used here serves only as a basis for embrittlement damage assessment. Engineering design-related temperatures can only be obtained using fracture-mechanics test methods supplemented with the technology 
of the Master Curve. A reference temperature, $T_{100}$, has been determined that corresponds to a median fracture toughness of $100 \mathrm{MPa} \sqrt{\mathrm{m}}$. Whenever sufficient material was left over after CVN specimens were taken, fracture-mechanics specimens (1/2T compacts) were made, and $T_{100}$ temperatures determined. These results are compared to CVN $\mathrm{T}_{\mathrm{o}}$ temperatures in Table 10 , columns 3 and 6 . The difference is nominally $90^{\circ} \mathrm{C}$. A crude correlation that is known to exist between Charpy transition curves and $T_{100}$ did not work well with these temper-embrittled steels. Columns 5 and 6 would have been reasonably close if the expected relationship had existed.

Table 10. Comparison of Charpy $V T_{0}$ and fracture-mechanics-based $T_{100}$ temperatures

\begin{tabular}{|c|c|c|c|c|c|c|}
\hline \multirow[t]{2}{*}{ Material } & \multirow{2}{*}{$\begin{array}{l}\text { Aging } \\
\text { treatment } \\
\left(\mathrm{h} /{ }^{\circ} \mathrm{C}\right)\end{array}$} & \multicolumn{2}{|c|}{$\begin{array}{l}\text { CVN } \\
\text { temperatures } \\
\left({ }^{\circ} \mathrm{C}\right)\end{array}$} & \multicolumn{3}{|c|}{$\begin{array}{l}\text { Fracture mechanics } \mathrm{T}_{100} \\
\left({ }^{\circ} \mathrm{C}\right)\end{array}$} \\
\hline & & $\mathrm{T}_{\mathrm{o}}{ }^{a}$ & $T_{28 J}^{b}$ & $T_{28 \mathrm{~J}}-18$ & $T_{100^{c}}$ & Error $^{d}$ \\
\hline \multirow[t]{2}{*}{ A 302 B } & $2000 / 450$ & 45 & 14.2 & -4 & -30 & 26 \\
\hline & $168 / 490$ & 44 & 18.0 & 0 & -38 & 38 \\
\hline \multirow[t]{2}{*}{ A 508} & $2000 / 450$ & 41 & -30 & -48 & -84 & 36 \\
\hline & $168 / 490$ & 16 & -24 & -42 & -36 & -6 \\
\hline \multirow[t]{3}{*}{ A 533 B } & $2000 / 450$ & 78 & 48 & 30 & 5 & 25 \\
\hline & $168 / 490$ & 65 & 2.0 & -16 & -49 & 33 \\
\hline & $2000 / 450+168 / 490$ & 66 & 46 & 28 & -21 & 49 \\
\hline Mod A 302 B & As received & 9 & -70 & -88 & -88 & 0 \\
\hline \multicolumn{7}{|c|}{ 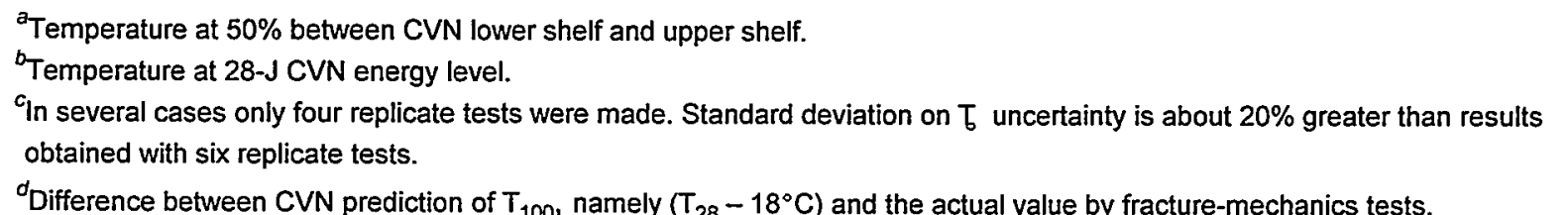 } \\
\hline
\end{tabular}




\section{CONCLUSIONS}

The postulate that unirradiated RPV welds might contain LBZs could not be supported by the results of this study. Almost every aspect of the findings of the problems associated with welding low-carbon microalloyed steels in offshore structures could not be rationalized as directly applicable to the reactor vessel multipass welding situation. However, in view of the findings of the AEA-Technology study, it was necessary to take into consideration the potential for temper embrittlement in the coarse-grain region of the HAZ. The AEA findings were essentially verified using five commercially made RPV steels. Gleeble simulation of an HAZ weld cycle was used to simulate the real-case metallurgical conditions. Temper embrittlement was not found at an aging temperature of $399^{\circ} \mathrm{C}\left(750^{\circ} \mathrm{F}\right)$, so it appears that the RPV operating temperature of $288^{\circ} \mathrm{C}\left(550^{\circ} \mathrm{F}\right)$ may not create a problem unless synergistic interactions with neutron irradiation occur. The experiment to investigate this postulated mechanism is in progress, and its results will also include the possibility of what might happen if recovery annealing of RPVs were introduced in future years.

In this study, aging at 450 and $482^{\circ} \mathrm{C}\left(842\right.$ and $\left.900^{\circ} \mathrm{F}\right)$ for $168 \mathrm{~h}$ of soak time was investigated. Temper embrittlement was noted, but the transition temperatures of the initial conditions were so low that the CVN $T_{0}$ temperatures did not even reach room temperature. Additionally, these $\mathrm{T}_{0}$ values were on average about $90^{\circ} \mathrm{C}\left(162^{\circ} \mathrm{F}\right)$ higher

than the $T_{100}$ transition temperatures related to in-service performance. Therefore, unless there are results to the contrary from the irradiation exposures, this investigation does not support the postulate of an LBZ problem in RPV welds.

\section{ACKNOWLEDGMENTS}

The author is indebted to the late Dr. Michael Vassilaros of the NRC, who assisted with the evaluations as the work progressed. Assistance at ORNL is also greatly appreciated: Alan Frederick for Gleeble austenitization, Edward Hatfield for heat treatment, Janie Gardner and Jackie Mayotte for metallurgy, Ronald Swain for mechanical tests, 
James King for welding technology guidance, Lee Heatherly for auger analysis, and Julia Bishop for preparation of the report.

\section{REFERENCES}

1. D. P. Fairchild, "Fracture Toughness Testing of Weld Heat Affected Zones in Structural Steel," pp. 117-141 in Fatigue and Fracture Testing of Weldments, ASTM STP 1058, H. I. McHenry and J. M. Potter, Eds., American Society for Testing and Materials, Philadelphia, 1990.

2. C. Thaulow, O. M. Kselsen, M. Houge, B. Melve, A. J. Paauw, G. Rorvik, J. K. Solberg, and J. Troset, "Fracture Mechanics Testing of HSLA Steels for Offshore Applications," pp. 195-204 in Proceedings of ASM Conference on Microalloyed Steels, Vol. 8811-003, World Materials Congress, Chicago, 1988.

3. C. Thaulow, A. J. Paauw, and G. Rorvik, "Fracture Mechanics Testing of Weld Metal for Low-Carbon Microalloyed Steels," pp. 277-301 in TMS Symposium on Welding Metallurgy, Denver, February 1987.

4. C. Thaulow, A. J. Paauw, and K. Guttormsen, "The Heat-Affected Zone Toughness of Low-Carbon Microalloyed Steels," The Welding Journal, 9 , 266-s-279-s (September 1987).

5. The British Standards Institution, "Methods for Crack Opening Displacement (COD) Testing," BS 5762, 1979.

6. "API Specification for Production Qualification for Steel Plates for Offshore Structures," API RP2Z, American Petroleum Institute, Dallas, March 1987.

7. "Steel Specification for Fixed Offshore Structures," EEMUA Publication No. 150, Engineering Equipment and Materials Users Association, London, 1987.

8. A. J. R. Loureiro and A. A. Fernandes, "Toughness of CGHAZs of Welds in $Q$ and T Steels," The Welding Journal Supplement, 9, 225-s-232-s (September 1994). 
9. A. M. Barnes, The Effect of Intercritical Thermal Cycles on HAZ Microstructure and Toughness in C-Mn-Al-Nb Steel, Report 402/1989, The Welding Institute, August 1989.

10. K. Arimochi, "CTOD Behavior of Steel Weld with $500 \mathrm{MPa}$ Class Strength and HAZ-CTOD Characteristics of Newly Developed Low AI-B-N Steel," Transactions of the Japan Welding Society, 20(2), 1989.

11. C. Thaulow and A. J. Paaw, "Materials Characterization with Respect to HAZ Local Brittle Zones," pp. 24-1 to 24-14 in WELDTECH 88, London, November 1988.

12. A. Barnes, "Local Brittle Zones in C-Mn Steel Multipass Welds," The Welding Institute Bulletin, September/October 1990.

13. R. J. McElroy, A. J. E. Foreman, G. Gage, W. J. Phythian, P. H. N. Ray, and I. A. Vatter, "Optimization of Reactor Pressure Vessel Surveillance Programmes and Their Analysis," contribution to IAEA CRP 3 Research Program, AEA-RS-2426, December 1993.

14. J. A. Wang, Embrittlement Data Base, Version 1, USNRC Report, NUREG/ CR-5506 (ORNL/TM-13327), August 1999.

15. C. D. Lundin and S. Mohammed, Effect of Welding Conditions on Transformation and Properties of Heat-Affected Zones in LWR Vessel Steels, USNRC Report NUREG/CR-3873 (ORNL/SUB/78-7637/1), November 1990.

16. S. R. Ortner, J. A. Mace, J. Hyde, and C. A. English, "Grain Boundary Analysis in RPV Steels After HAZ-Simulating Treatment and Aging," AEAT-5292, March 1999.

17. D. E. McCabe and R. K. Nanstad, "Evaluation of the Potential of RPV Steels HAZ for Temper Embrittlement," Proceedings of IGRDM Meetings, Nashville, Tennessee, January 18-22, 1999. 


\section{APPENDIX}

Examples of HAZ Coarse Grains Along Fusion Line, Fine Prior-Austenite Grain Zones, and Base Metal Grains from Three Selected Commercial Welds 


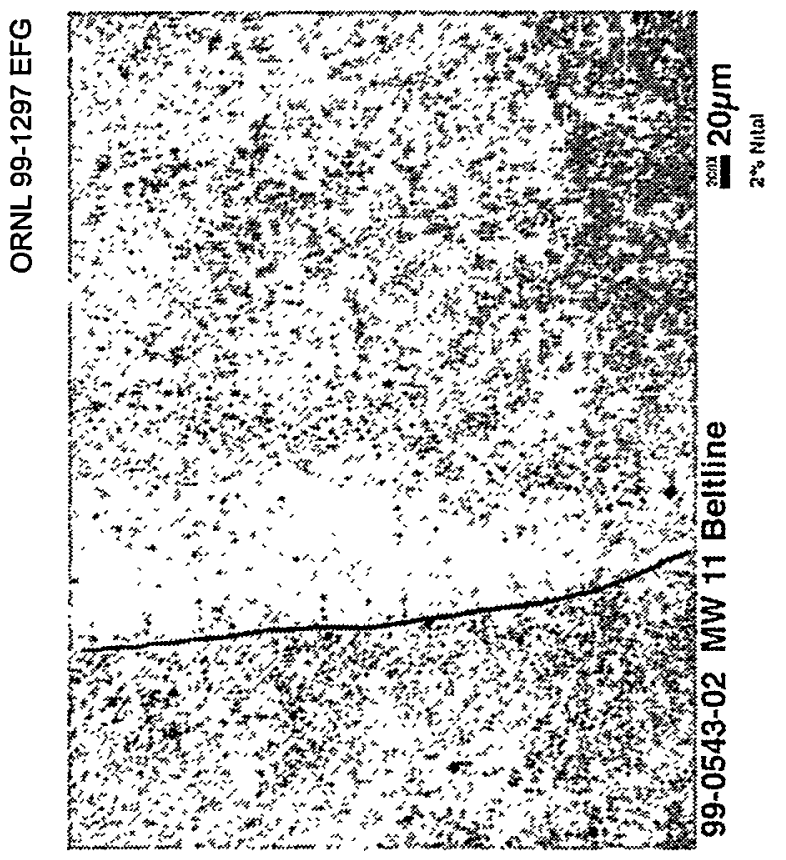

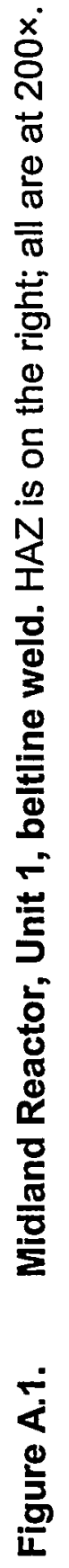
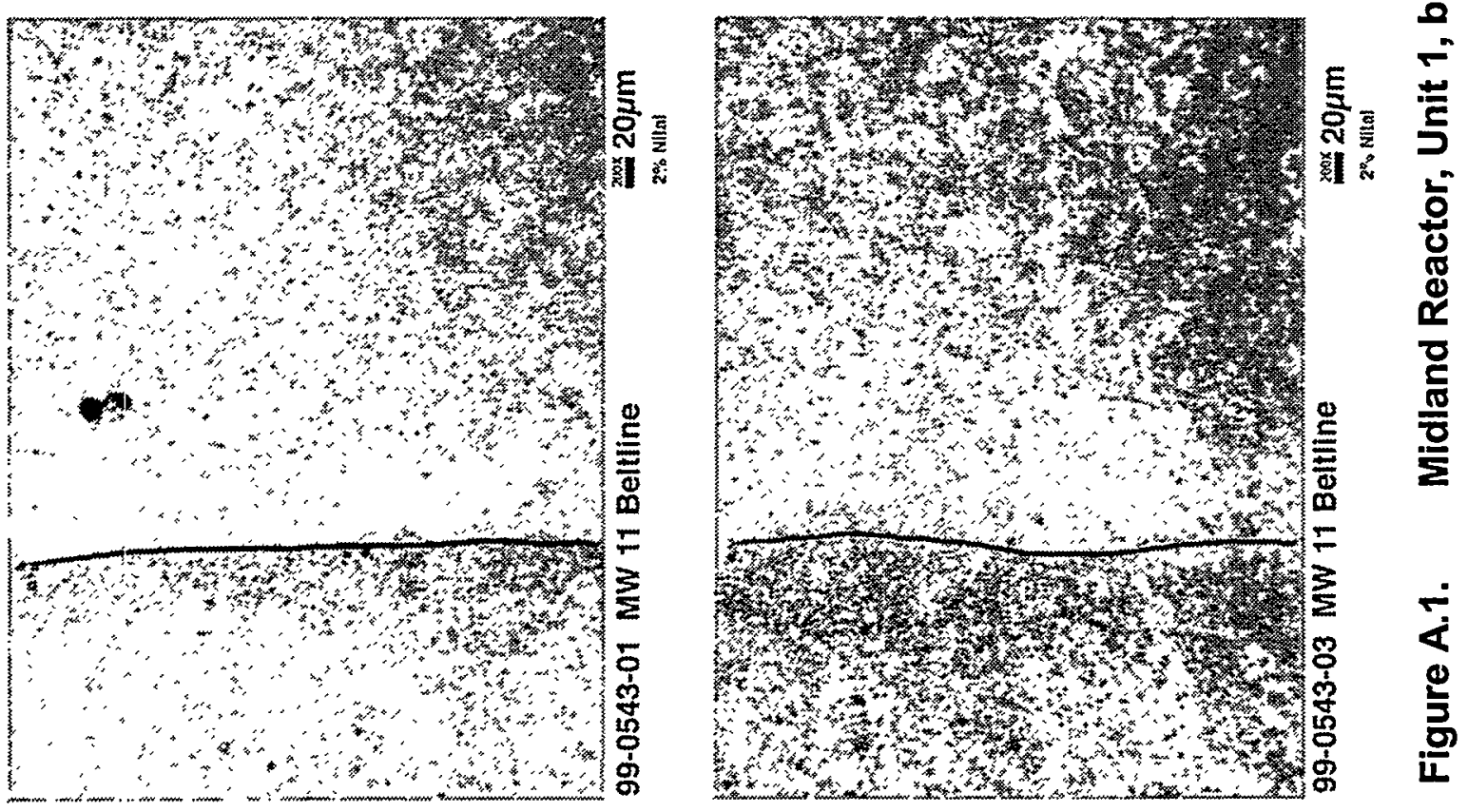

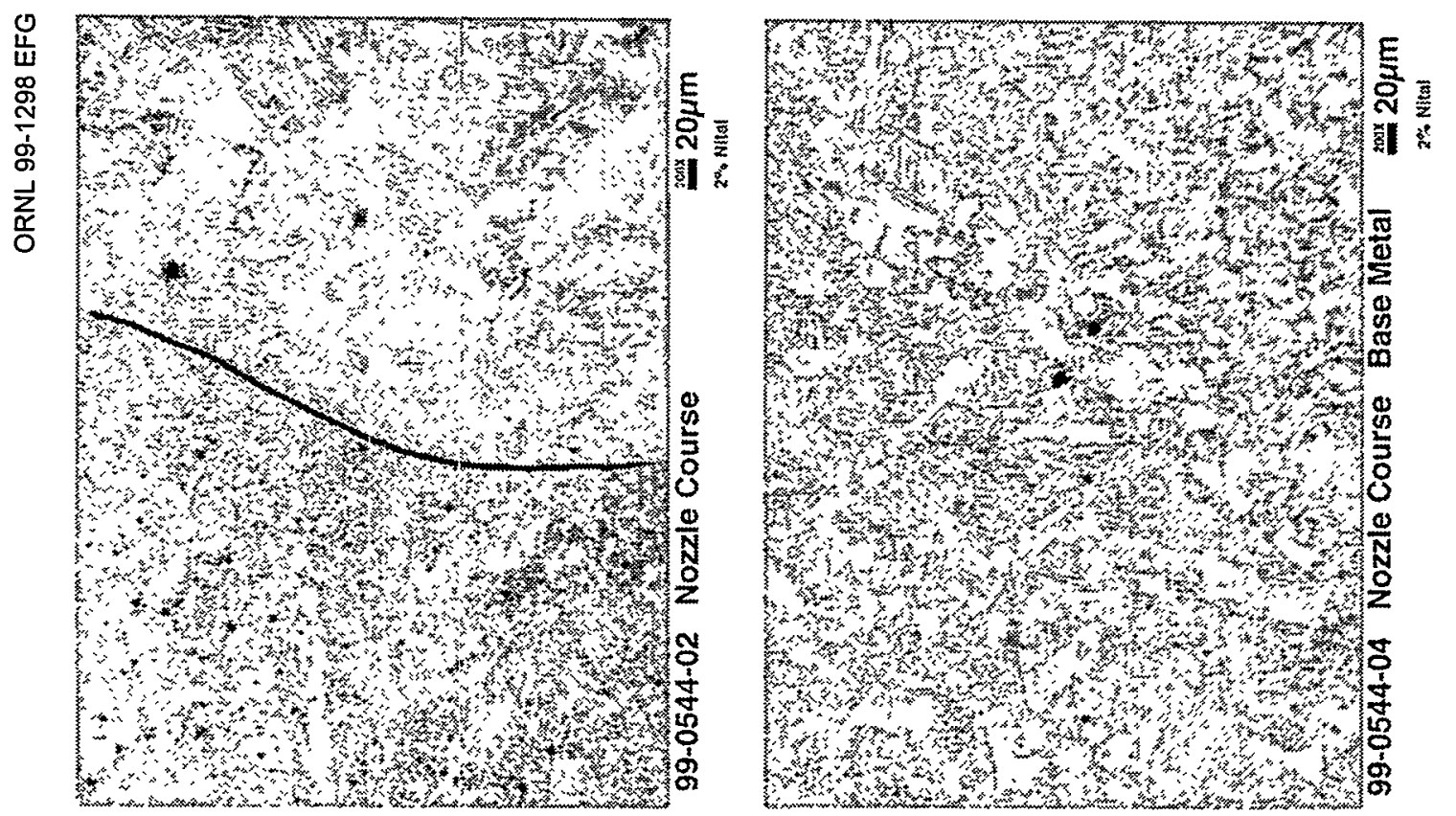

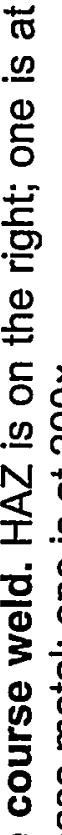
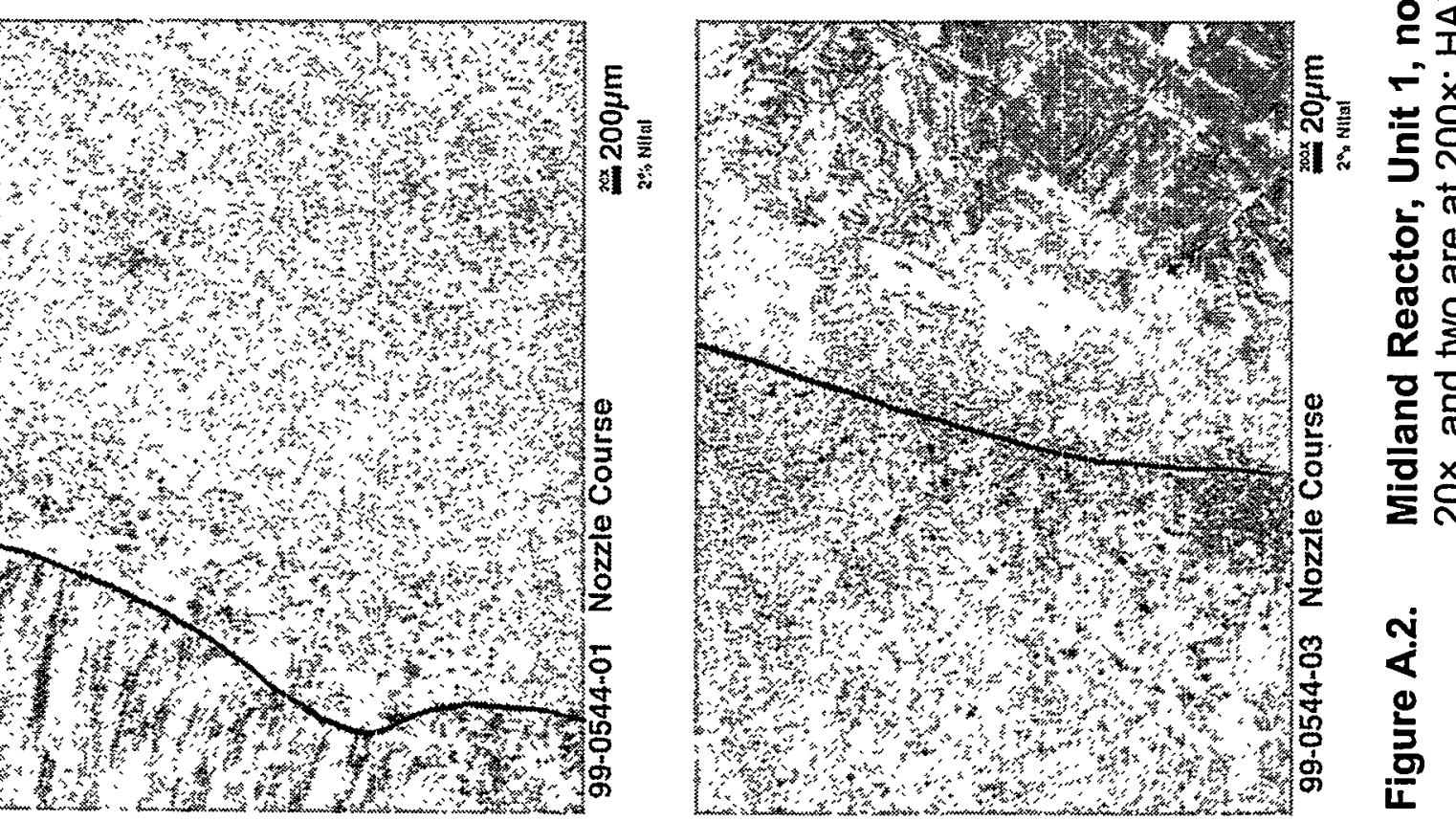

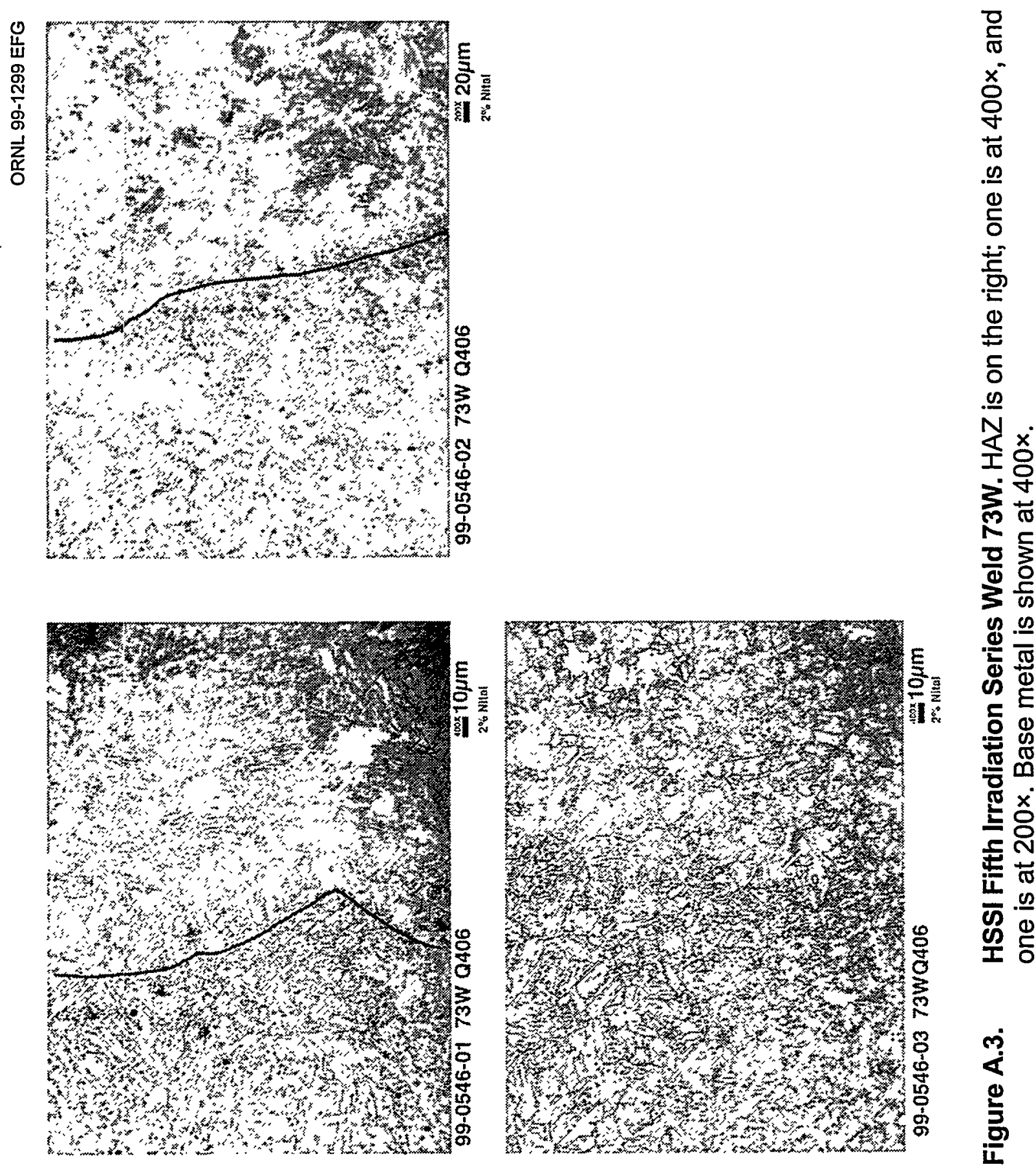


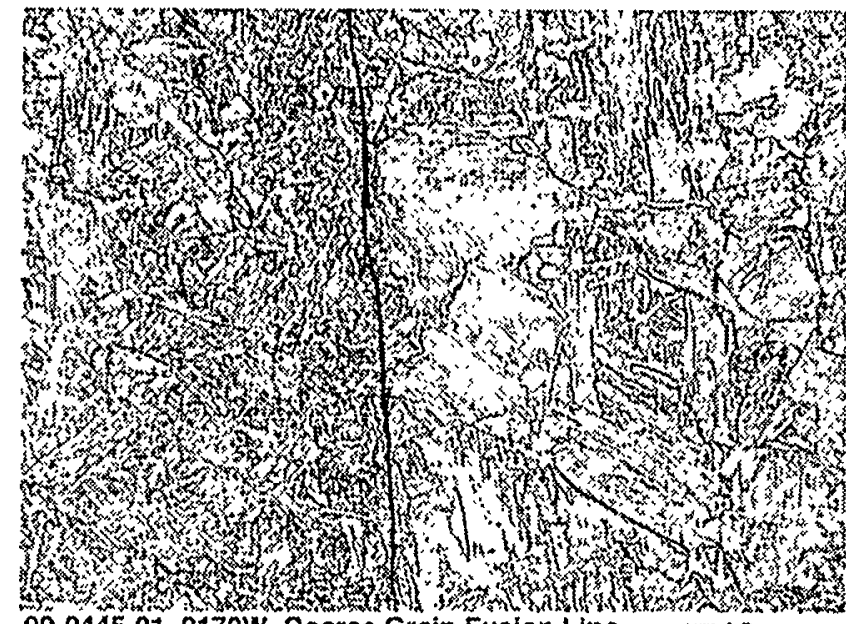

99-0445-01 0172W Coarse Grain Fusion Line

$$
{ }_{20}^{\circ} \mathrm{sinat}
$$

’

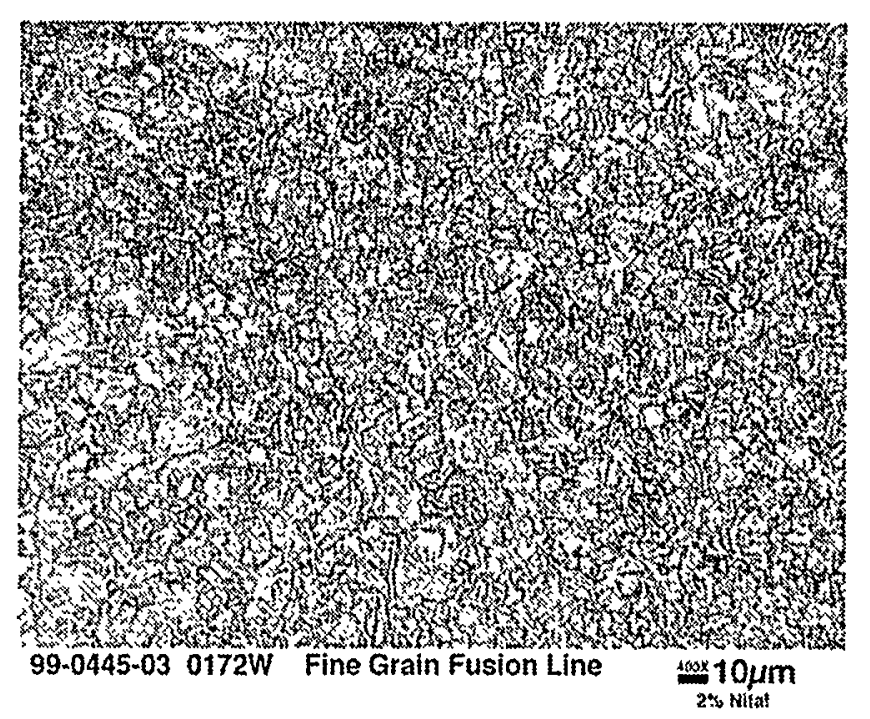

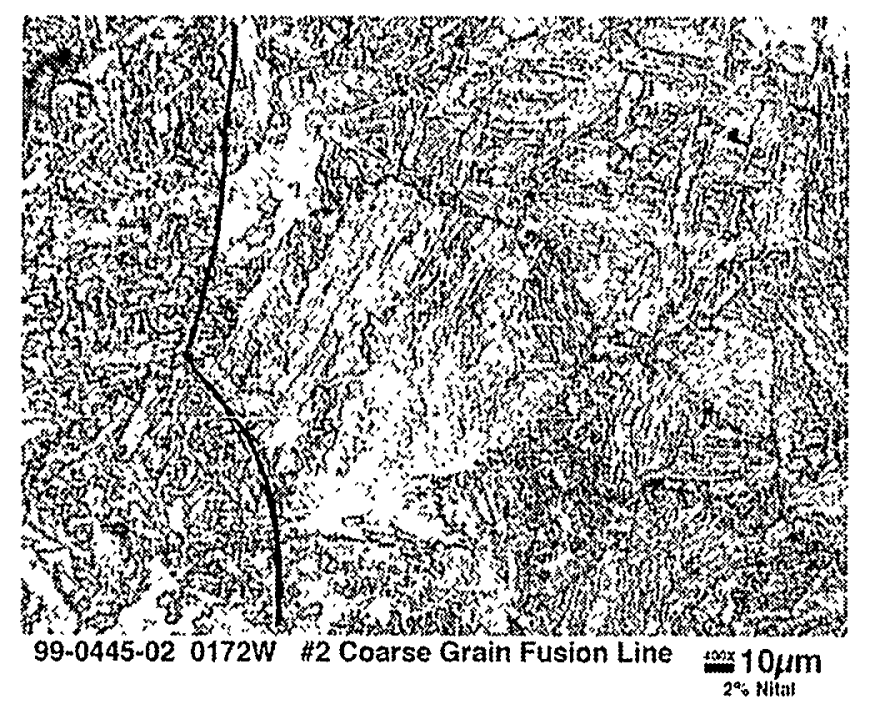

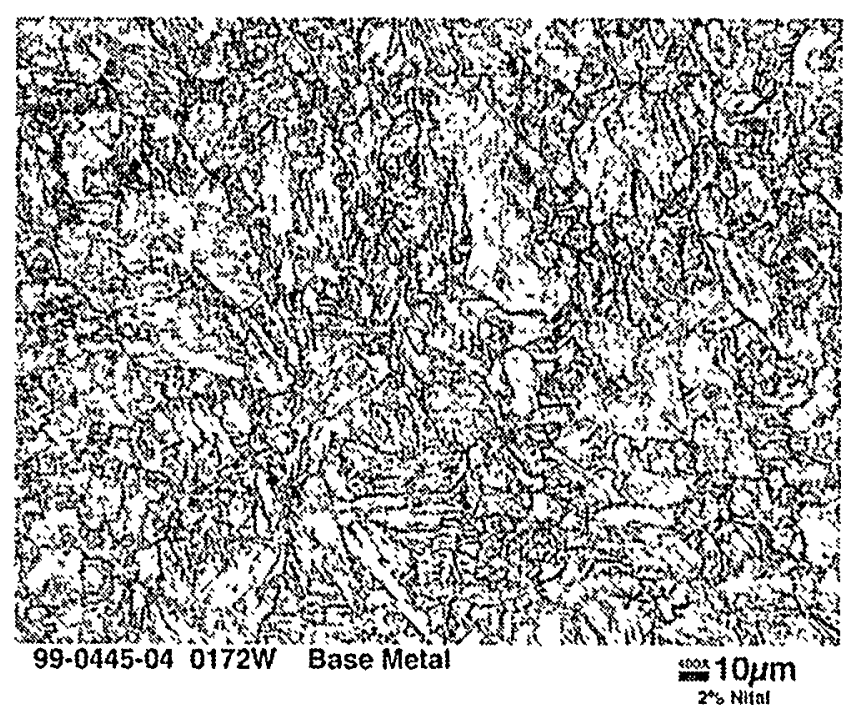

Figure A.4. HSSI Fifth Irradiation Series Weld 72W. HAZ is on the right; two are at 400x, fine-grain HAZ (FGHAZ, Fig. 1), and one is at 400x. Base metal is shown at $400 x$. 
ORNL 99-1301 EFG
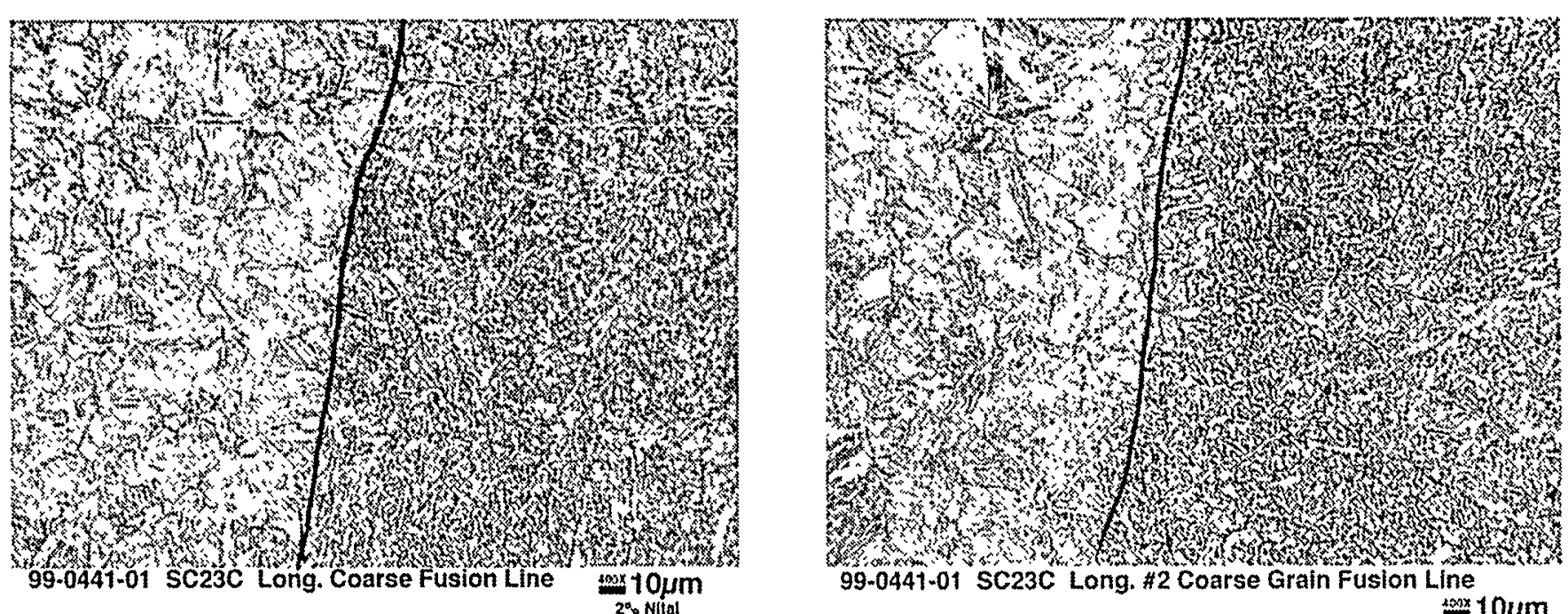
99-0441-01 SC23C Long. \#2 Coarse Grain Fusion Line

$$
10 x+10 \mu m
$$
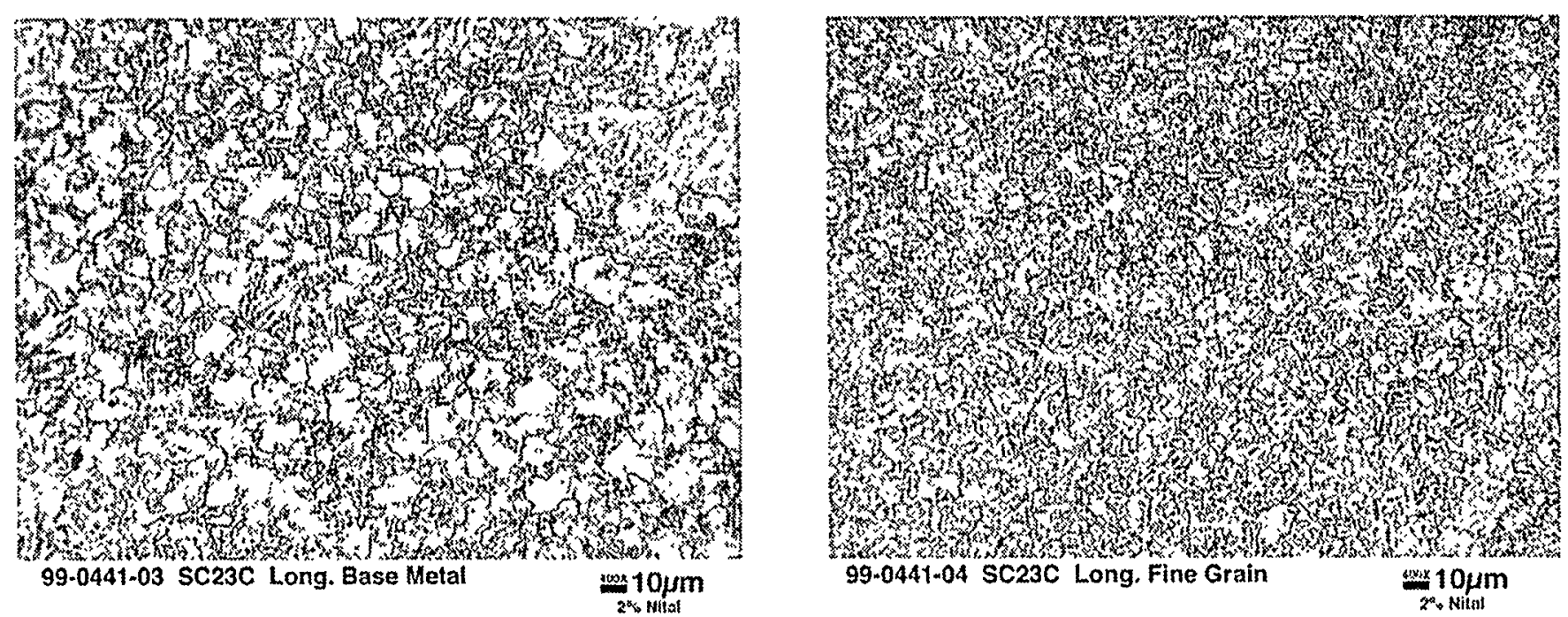

Figure A.5. SNUPPS longitudinal weld. $H A Z$ is on the right; one is at $400 x$, fine-grain $H A Z$ (FGHAZ, Fig. 1); one is at $400 \times$. Base metal is shown at $400 \times$. 

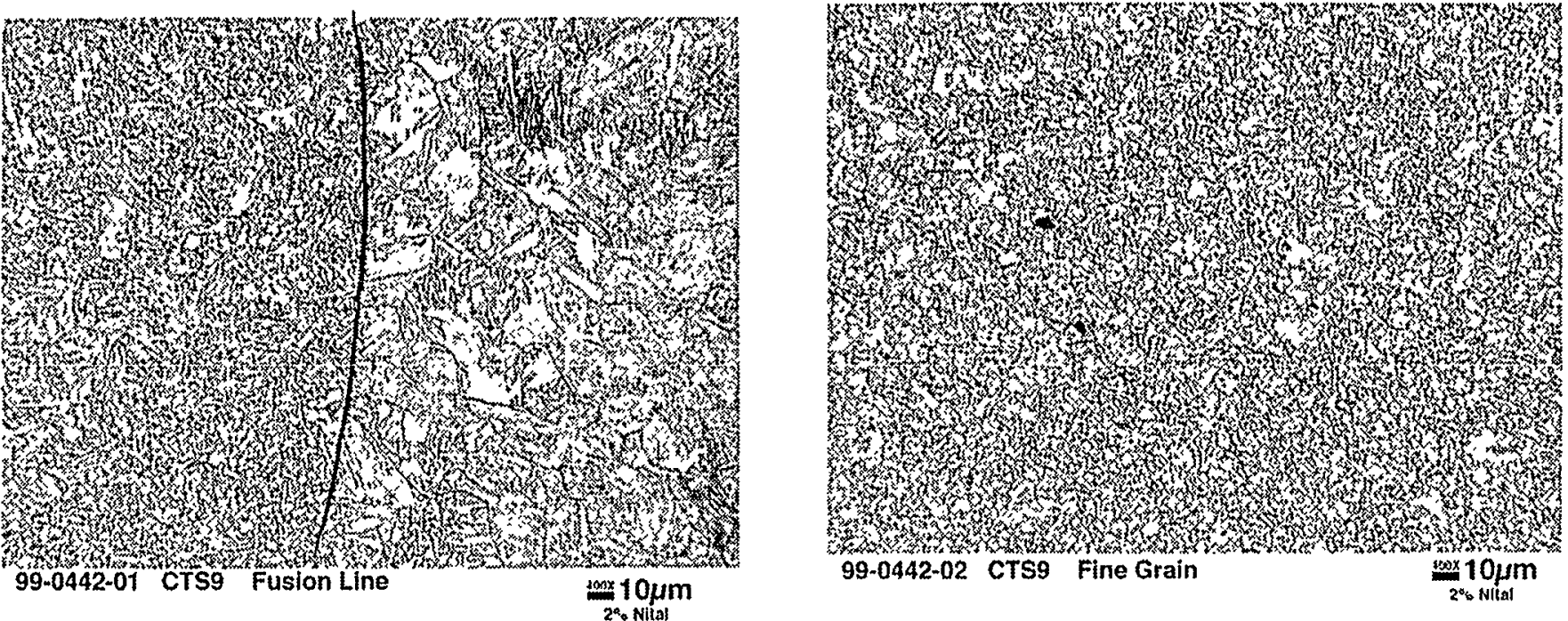

$\underset{\infty}{>}$

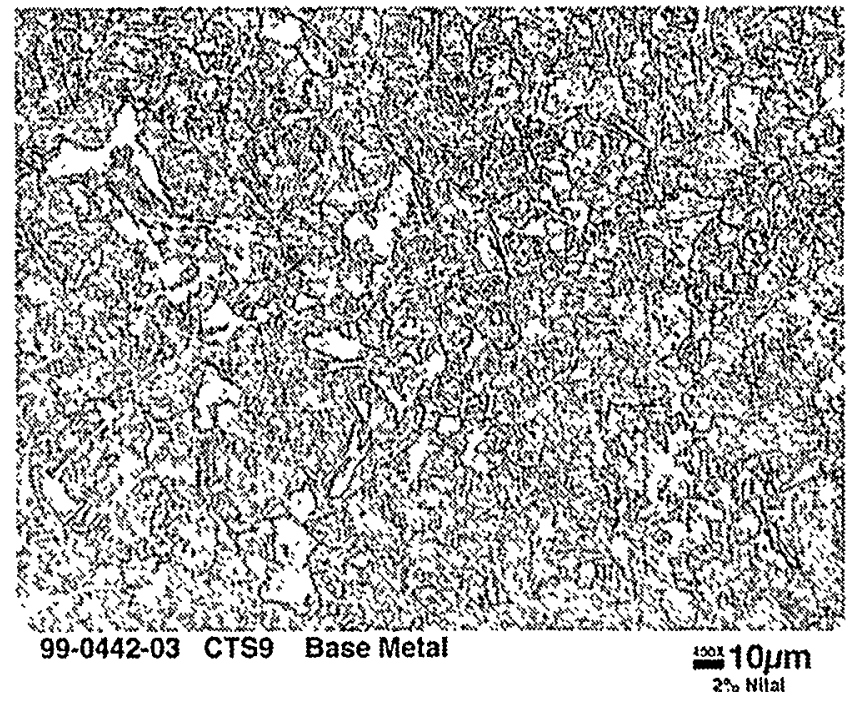

Figure A.6. SNUPPS beltline weld. HAZ is on the right; two are at $200 x$, and one is at $100 \times$. 


\section{INTERNAL DISTRIBUTION}

1. B. R. Bass

2. E. E. Bloom

3. J.W. Bryson

4. R. D. Cheverton

5. S. A. David

6. T. L. Dickson

7. A. Frederick

8. H. W. Hayden, Jr.

9. S. K. Iskander

10. J. F. King

11. W. Koncinski

12. W. J. McAfee
13-18. D. E. McCabe

19. J. G. Merkle

20-22. R. K. Nanstad

23. C. E. Pugh

24-26. T. M. Rosseel

27. V. K. Sikka

28. M. A. Sokolov

29. R. E. Stoller

30. R. L. Swain

31. Central Research Library

32. ORNL Laboratory Records

33. ORNL Laboratory Records

\section{EXTERNAL DISTRIBUTION}

34. ABB-COMBUSTION ENGINEERING, P.O. Box 500, Department 9632-1922, 2000 Day Hill Road, Windsor, CT 06095

D. Ayers

35-36. AEA TECHNOLOGY, 220 Harwell, Thermal Reactor Services, Didcot, Oxfordshire, OXII, ORA, United Kingdom

C. A. English

37. ATI Consulting, Suite 160, 3860 Blackhawk Rd., Danville, CA 94506

W. L. Server

38-45. U.S. NUCLEAR REGULATORY COMMISSION, Office of Nuclear Regulatory Research, MS T10-E10, Washington, DC 20555
J. W. Craig
C. J. Fairbanks (2)
E. M. Hackett
A. L. Hiser
M. T. Kirk
S. N. M. Malik
M. E. Mayfield 
46-48. WESTINGHOUSE ELECTRIC CORP., P.O. Box 355, Pittsburgh, PA 15320

W. H. Bamford

C. Kim

R. Lott 